\section{Smith ScholarWorks}

$1-1-2014$

\section{Discontinuity Surfaces in Upper Cretaceous to Paleogene Carbonates of Central Dalmatia (Croatia): Glossifungites Ichnofacies, Biogenic Calcretes, and Stratigraphic Implications}

Mihovil Brlek

Croatian Geological Survey

Tvrtko Korbar

Croatian Geological Survey

Adrijan Košir

Znanstvenoraziskovalni center Slovenske akademije znanosti in umetnosti

Bosiljka Glumac

Smith College, bglumac@smith.edu

Anita Grizelj

Croatian Geological Survey

See next page for additional authors

Follow this and additional works at: https://scholarworks.smith.edu/geo_facpubs

Part of the Geology Commons

\section{Recommended Citation}

Brlek, Mihovil; Korbar, Tvrtko; Košir, Adrijan; Glumac, Bosiljka; Grizelj, Anita; and Otoničar, Bojan, "Discontinuity Surfaces in Upper Cretaceous to Paleogene Carbonates of Central Dalmatia (Croatia): Glossifungites Ichnofacies, Biogenic Calcretes, and Stratigraphic Implications" (2014). Geosciences: Faculty Publications, Smith College, Northampton, MA.

https://scholarworks.smith.edu/geo_facpubs/154 


\section{Authors}

Mihovil Brlek, Tvrtko Korbar, Adrijan Košir, Bosiljka Glumac, Anita Grizelj, and Bojan Otoničar 


\title{
Discontinuity surfaces in Upper Cretaceous to Paleogene carbonates of central Dalmatia (Croatia): Glossifungites ichnofacies, biogenic calcretes, and stratigraphic implications
}

\author{
Mihovil Brlek • Tvrtko Korbar • Adrijan Košir • \\ Bosiljka Glumac · Anita Grizelj · Bojan Otoničar
}

Received: 22 March 2013/Accepted: 5 July 2013/Published online: 20 July 2013

(c) Springer-Verlag Berlin Heidelberg 2013

\begin{abstract}
Substrate-controlled ichnofacies and biogenic calcretes represent key features for identification and interpretation of discontinuities in the carbonate rock record, which are of great significance for stratigraphic interpretations and correlations. Intraformational firmground and composite surfaces, as well as a regional Cretaceous to Paleogene (K-Pg) subaerial unconformity, developed in Upper Cretaceous to Paleogene intra-platform peritidal successions in central Dalmatia, Croatia (AdriaticDinaridic Carbonate Platform, ADCP), were analyzed for their trace fossil and subaerial exposure features. Thalassinoides (probably T. paradoxicus) box-work burrow systems of the substrate-controlled Glossifungites ichnofacies characterize the two documented firmgrounds and one composite (polygenic) surface. Rhizogenic laminar calcretes developed subsequently inside burrows of the composite surface through diagenetic overprint of marine sediment that passively infilled the burrows. While the formation of the two firmgrounds was probably caused by cessation of precipitation and/or deposition of calcium
\end{abstract}

M. Brlek $(\varangle) \cdot$ T. Korbar · A. Grizelj

Department of Geology, Croatian Geological Survey,

Sachsova 2, 10000 Zagreb, Croatia

e-mail: mihovil.brlek@hgi-cgs.hr

\section{A. Košir}

Institute of Palaeontology ZRC SAZU, Novi trg 2,

1000 Ljubljana, Slovenia

\section{B. Glumac}

Department of Geosciences, Smith College,

Northampton, MA 01063, USA

B. Otoničar

Karst Research Institute ZRC SAZU, Titov trg 2,

6230 Postojna, Slovenia carbonate due to relative sea-level fall, the recorded trace fossils associated with the composite surface indicate that this surface developed through both submarine firmground and subaerial exposure stages probably caused by several episodes of regression and transgression, and exemplifies the general complexity of hiatal surfaces in shallow-marine carbonate successions. The regional $\mathrm{K}-\mathrm{Pg}$ subaerial unconformity is characterized by biogenic (beta microfabric) calcretes with rhizoliths including Microcodium aggregates, root tubules, as well as alveolar-septal structures. Laminar calcretes and pisoids, together with in situ and resedimented speleothems, and bauxitic deposits, were also recorded. The unconformity developed due to formation of a forebulge in front of the approaching Dinaridic orogen. Ichnological and subaerial exposure features, together with stratigraphic implications derived from the analyzed discontinuities, serve as examples that can be applied to discontinuities present in carbonate successions elsewhere.

Keywords Discontinuity surfaces - Glossifungites ichnofacies · Biogenic calcretes · Upper Cretaceous to Paleogene Croatia

\section{Introduction}

Discontinuity surfaces (or discontinuities) resulting from breaks in sedimentation and representing hiatuses independent of their duration are common features in the sedimentary record (Clari et al. 1995; Hillgärtner 1998). Such surfaces are useful marker horizons for correlation of stratigraphic sections and are highly applicable in carbonate sequence stratigraphy (e.g., Wright 1994; Buatois and Mángano 2011; Schwarz and Buatois 2012). The 
significance of substrate-controlled trace fossil suites and calcretes for genetic interpretations of discontinuity surfaces has been emphasized by many researchers (e.g., Bromley 1975; Wright 1994; Hillgärtner 1998; Schwarz and Buatois 2012).

Marine omission surfaces are clearly marked by substrate-controlled trace fossil suites (Bromley 1975; Fürsich 1979; Knaust et al. 2012; Savrda 2012; Schwarz and Buatois 2012), with progressive hardening of the substrate demonstrated by cross-cutting vertical relationships between the pre-lithification Glossifungites ichnofacies (firmgrounds) and the post-lithification Trypanites ichnofacies (hardgrounds) (Bromley 1975; Savrda 2012). Composite (polygenic) surfaces, which record both marine omission and subaerial exposure stages (Sattler et al. 2005; Rameil et al. 2012), are also commonly marked by substrate-controlled trace fossil suites and calcretes (e.g., Wilson et al. 1998), and indicate the complexity of hiatal surfaces in carbonate rock successions (Rameil et al. 2012).

Biogenic calcretes with rhizoliths represent profound indicators of subaerial exposure of carbonate successions (Wright 1994). In addition, subaerial exposure surfaces characterized by hiatuses on the order of several My in duration are commonly marked by well-developed paleokarstic horizons and bauxitic deposits (D'Argenio and Mindszenty 1995), and may reflect significant environmental changes in response to global, long-term processes of tectono-eustatic origin (Clari et al. 1995; D'Argenio and Mindszenty 1995; Hillgärtner 1998).

There are only a few records of detailed ichnological, sedimentological, and diagenetic analyses of discontinuity surfaces occurring in the Mesozoic to Cenozoic carbonate successions of the External Dinarides (e.g., Radoičić 1982, 1987; Babić and Zupanič 2012; Brlek et al. 2012; Martinuš et al. 2012). The purpose of the present study is to describe and interpret various types of discontinuity surfaces in terms of associated trace fossils and subaerial exposure features from the Upper Cretaceous to Paleogene carbonates of central Dalmatia (Croatia), which include marine firmgrounds and a composite (polygenic) surface characterized by both firmground burrows and rhizogenic calcretes, as well as a regional Cretaceous to Paleogene (K-Pg) subaerial unconformity. Furthermore, stratigraphic implications derived from these surfaces, including sequence stratigraphic interpretations or their relationship to major tectonic events, are discussed. These examples can be applied to discontinuities present in other shallowwater carbonate rock successions.

The study area is located on the northeastern Adriatic coast of central Dalmatia (Šibenik locality) and in the Adriatic Sea near the northeastern Adriatic coast (Island of Hvar), Croatia (Fig. 1a, b). The well-exposed Coniacian to Santonian Gornji Humac Formation (Šibenik locality;
Fig. 1c), and the Maastrichtian to Paleocene Sumartin Formation (Hvar locality; Fig. 1d) (Gušić and Jelaska 1990; Steuber et al. 2005) provide an ideal study area, with both formations being overlain by transgressive Paleogene (Eocene) carbonates across the regional K-Pg subaerial unconformity. The latter developed due to formation of a forebulge in front of the approaching Dinaridic orogen, and is characterized by well-developed paleosol and paleokarst features (D'Argenio and Mindszenty 1995; Mindszenty et al. 1995; Durn et al. 2003; Otoničar 2007; Korbar 2009). These features, together with well-developed trace fossils associated with several intraformational discontinuities in the Gornji Humac Formation, represent the focus of this study.

\section{Geological setting and stratigraphy}

The Upper Cretaceous to Paleogene carbonates from the Šibenik (Fig. 1a-c) and Hvar (Fig. 1a, b, d) localities were deposited in the southern part of the long-lasting (Late Triassic to Paleogene) Adriatic-Dinaridic Carbonate Platform (ADCP) (sensu lato, cf. Pamić et al. 1998). This carbonate platform was a typical central Tethyan ("periAdriatic") or central-northern Mediterranean Mesozoic (sub)tropical archipelago, characterized by a very thick succession of carbonate deposits and a complex large-scale facies architecture (Vlahović et al. 2005). The typical Upper Cretaceous stratigraphy of the south-central part of the Adriatic Carbonate Platform (ACP) (sensu stricto, cf. Jenkyns 1991; Korbar 2009) was described in detail from the neighboring Island of Brač (Gušić and Jelaska 1990; Cvetko Tešović et al. 2001; Moro et al. 2002; Steuber et al. 2005) and is characterized by a more than 1500 -m-thick peritidal succession punctuated by two drowning episodes. Upper Cretaceous to Paleogene deeper-water slope and ramp deposits recorded along the NE Adriatic coast of Croatia in central and southern Dalmatia (e.g., Vlahović et al. 2005; Ćosović et al. 2006; Korbar 2009; Brlek et al. 2012) indicate differentiated depositional settings in the ADCP domain and a rather complex depositional, tectonostratigraphic and paleogeographic setting of the region in Late Cretaceous to Paleogene times.

The Gornji Humac Formation extends regionally across the ADCP domain (see Korbar 2009 and references therein). Similar peritidal lithology and biofacies (assemblages of rudists, benthic foraminifera, thaumatoporellaceans and Decastronema sp.) also characterize the succession in the Šibenik region in general (including the Ravni Žakan Island in the Kornati archipelago, Adriatic Sea; Korbar et al. 2010b) and at the Šibenik locality in particular (Fig. 2a). A Coniacian to Santonian age of the middle part of the Gornji Humac Formation was determined mainly from the assemblages of larger benthic 

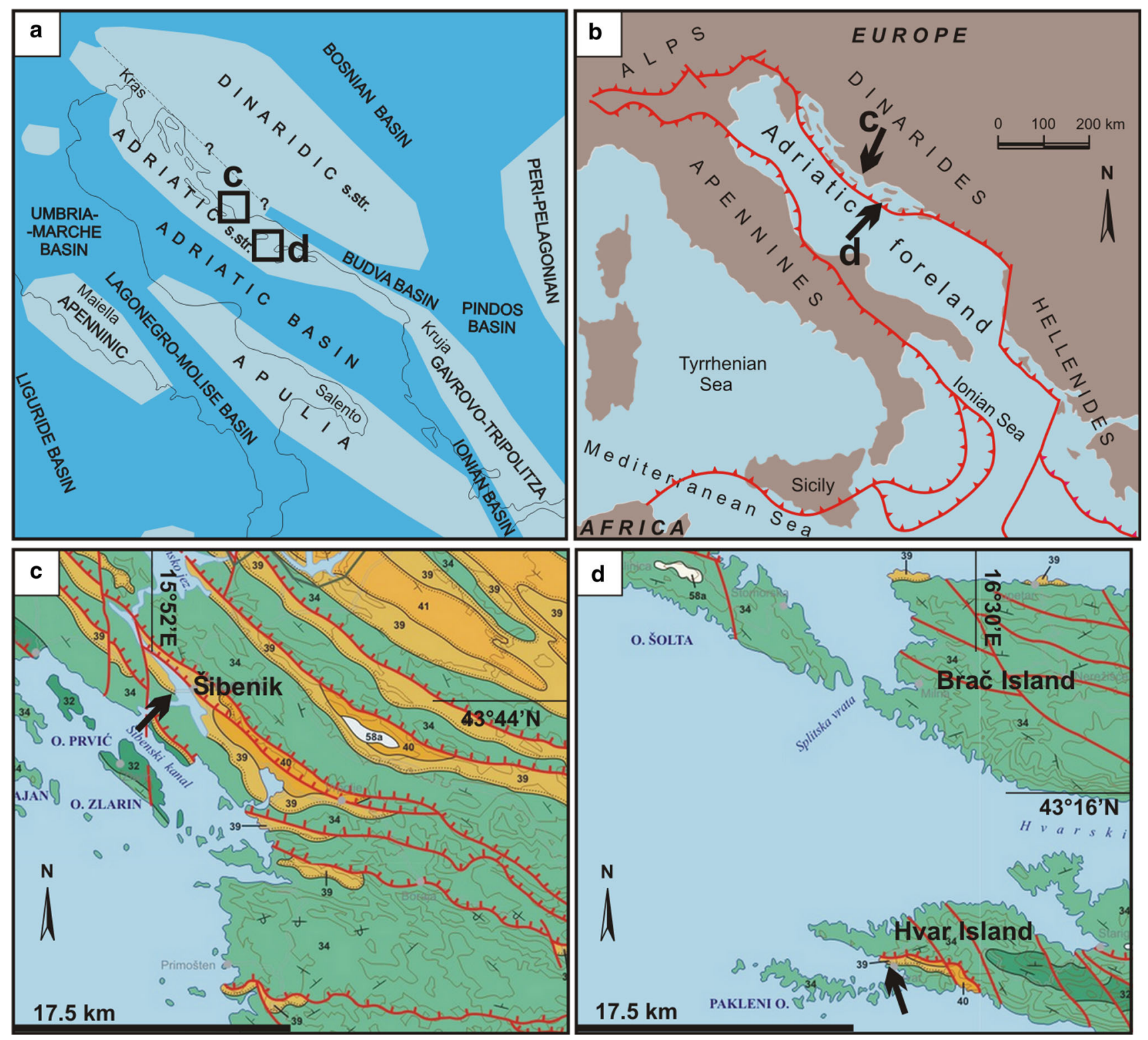

Fig. 1 Locality maps. a, b Position of the Šibenik (rectangle $c$ in a) and Hvar (rectangle $d$ in a) localities on the paleogeographic sketch-map (a) showing the peri-Adriatic carbonate platforms and shelves (light blue), and on the tectonic map (b; localities marked by black arrows) (modified from Korbar 2009). c, d Parts of the geological map of the Republic of Croatia 1:300.000 (GKRH 2009)

(marked by rectangles $c$ and $d$ in a) showing the simplified geology of central Dalmatia (Croatia) with position of the Sibenik (c, black arrow) and Hvar (d, black arrow) localities. Green Upper Cretaceous carbonates (34), orange Paleogene carbonates (39) and siliciclastics (40 and 41), white Quaternary deposits (58a)

foraminifera (Gušić and Jelaska 1990; Velić 2007), including Murgella lata Luperto Sinni which was also recorded in the Šibenik succession, as well as from strontium isotope stratigraphy (Steuber et al. 2005). A similar litho-/biofacies interpreted as inner shelf environment of a carbonate ramp setting was also recorded in the Southern Apennines, Italy (Carannante et al. 2000).

On the Croatian islands of Brač (Gušić and Jelaska 1990) and Hvar (Korbar et al. 2010a), the Sumartin Formation is represented by platform-interior carbonate

deposits, whose Late Campanian to Maastrichtian stratigraphic range is based on the correlation of strontium isotope data with documented benthic foraminifera, namely Murciella cuvillieri Fourcade, Rhapydionina liburnica Stache, and Laffiteina mengaudi Astre (biozones CsB6 and CsB7 cf. Fleury 1980, re-calibrated by Steuber et al. 2005). Detailed biostratigraphic and chemostratigraphic data, which confirm the Late Maastrichtian to Paleocene age of the Sumartin Formation analyzed here (Fig. 2b), will be presented in a separate paper. 
Fig. 2 Stratigraphic columns of the limestone succession of the Coniacian to Santonian Gornji Humac Formation and Maastrichtian to Paleocene Sumartin Formation (b) from the Šibenik and Hvar localities, respectively, with legend a

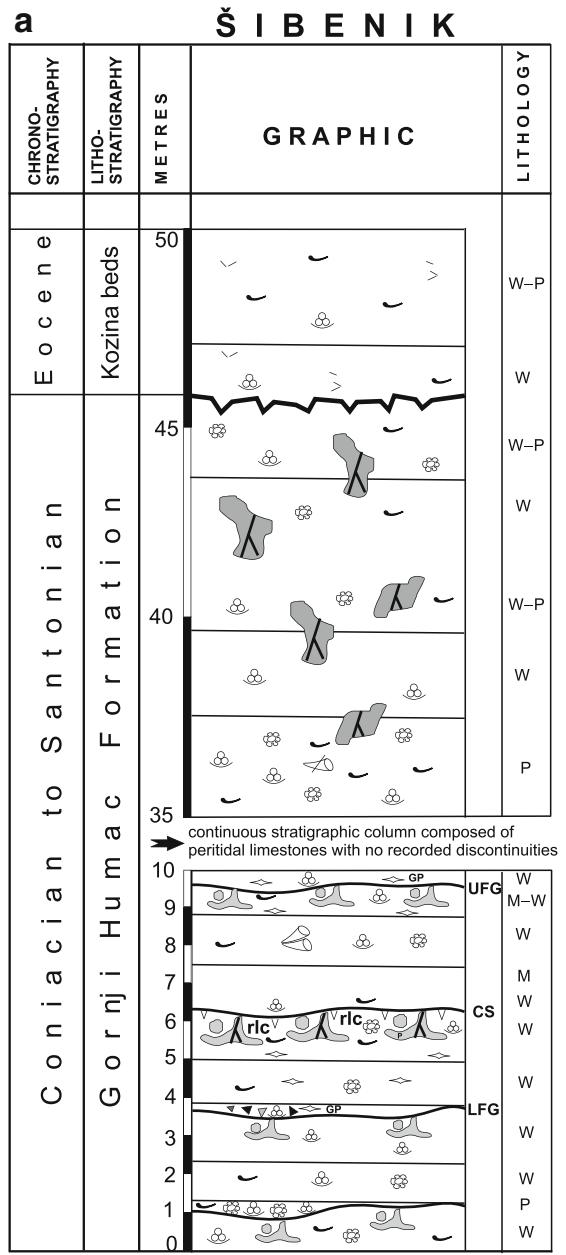

b

H V A R

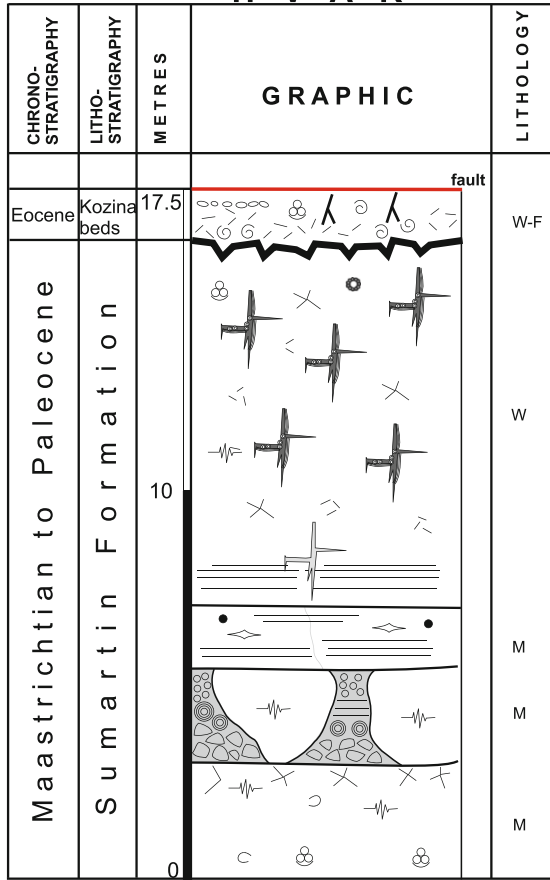

\section{LEGEND}

$\checkmark$ regional subaerial unconformity

biogenic (beta microfabic) calcrete Microcodium, root tubules) rlc rhizogenic laminar calcrete 1 laminated calcretes and pisoids $\sqrt{1}$ non-carbonate paleosol $=0$ paleokarstic sediment and breccia in-situ and resedimented

firmground

$\longrightarrow$ composite surface

Thalassinoides paradoxicus

Thaumatoporella

- Decastronema (Aeolisaccus)

3 benthic foraminifera

8 radiolitid rudists in parautochtonous

position

to rudist bioclasts

6 gastropods

c ostracods

- Charophyta

谷保 bioclasts

- peloids

$\propto \quad$ fenestrae

$\nabla_{\nabla} \wedge$ ? black pebbles

GP geopetal infill

-ip- stylolites

× recrystallization

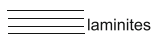

UFG upper firmground

LFG lower firmground

cs composite surface

M mudstone

W wackestone

$P$ packstone

M-W mudstone to wackestone

W-P wackestone to packstone

W-F wackestone to floatstone 
The Cretaceous to Paleogene (K-Pg) hiatus, recorded here as well as across the ADCP domain (e.g., Brlek et al. 2012), is a consequence of differential and diachronous uplift of several parts of the platform(s), interpreted as forebulging in front of the approaching Dinaric orogeny
(Otoničar 2007; Korbar 2009). Transgressive Paleogene deposits, which unconformably overlie the Gornji Humac and Sumartin formations at the Šibenik and Hvar localities, respectively (Fig. 2), are referred to as the Kozina beds unit. This unit occurs locally in the lowermost part of the
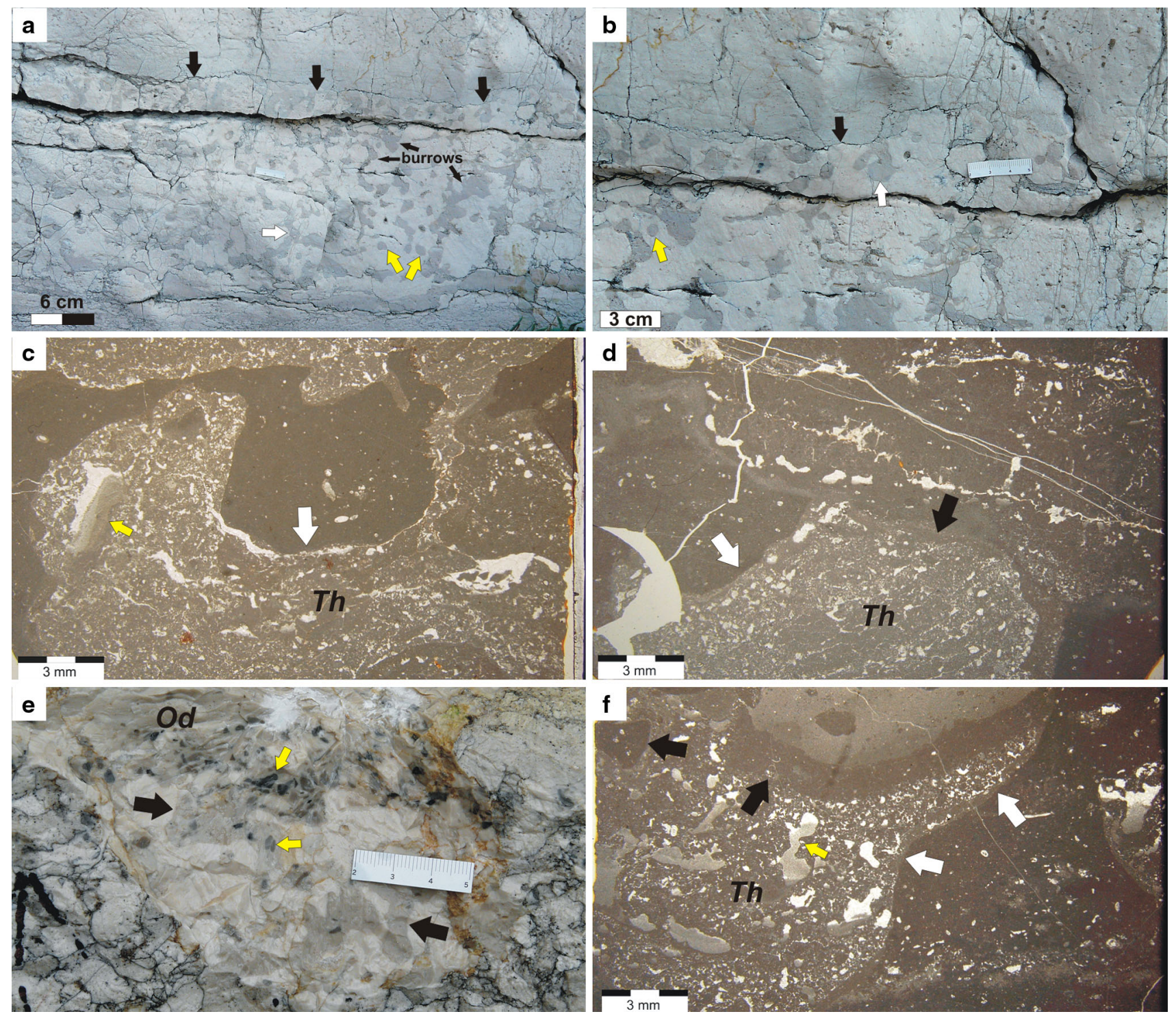

Fig. 3 Characteristics of the upper (a-d) and lower firmground $(\mathbf{e}, \mathbf{f})$ recorded in the Gornji Humac Formation (Šibenik locality; see also Fig. 2a). a, b Field exposure of a vertical section of the upper firmground with irregular morphology of the surface (with up to $2 \mathrm{~cm}$ of relief) and sharp contact with the overlying fenestral limestone (big black arrows). Bioclastic wackestone below the contact is penetrated by a complex system of Thalassinoides. These burrows have a sharp boundary and are unlined, irregular in size and shape, and may be of vertical, sub-vertical or horizontal orientation. Most are irregular and Y-branching (white arrows), but there are also some with sub-circular cross sections (yellow arrows). c, d Photomicrographs showing Thalassinoides $(T h)$ in sharp contact with the surrounding bioclastic wackestone (white arrows) and occluded by the overlying fenestral

wackestone with geopetally filled (micrite and/or vadose silt) fenestrae (yellow arrow). Black arrow in d shows the contact between the overlying fenestral wackestone and the firmground burrow (see white arrow in $\mathbf{b}$ ). e Field exposure of a vertical section of the lower firmground with the underlying bioclastic wackestone penetrated by irregular and branching Thalassinoides (black arrows), which are filled with the overlying deposits $(O d)$ containing black pebbles (yellow arrows). f Thalassinoides (Th) from the lower firmground, in sharp contact with the surrounding bioclastic packstone (white arrows). The burrow is filled with the overlying fenestral wackestone with black pebbles (black arrows). Fenestrae are geopetally filled with internal sediment (micrite) and/or vadose silt, as well as sparite (yellow arrow) 

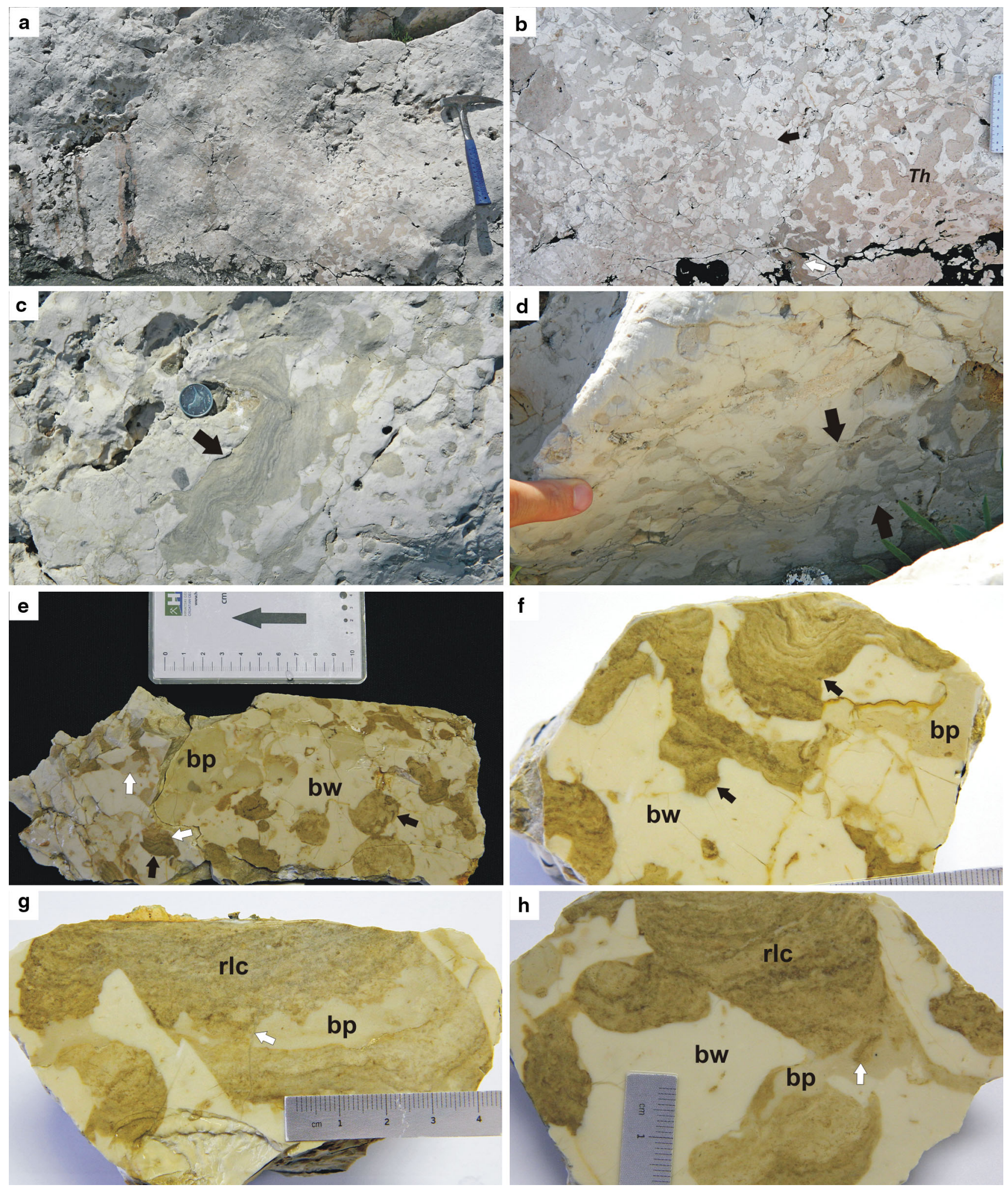

Lower to Middle Eocene Foraminiferal limestones, which are present regionally across the ADCP (Gušić and Jelaska 1990; Marjanac et al. 1998; Schweitzer et al. 2007; Ćosović et al. 2008; Korbar 2009; Korbar et al. 2010b).
The Foraminiferal limestones unit was deposited on a developing carbonate ramp (Ćosović et al. 2004) in the most distal parts of the foreland basins (Otoničar 2007; Zamagni et al. 2008; Korbar 2009). 
4 Fig. 4 Characteristics of the composite surface recorded in the Gornji Humac Formation (Šibenik locality; see Fig. 2a). a, b Bedding plane view of the composite surface penetrated by well-developed three-dimensional branching and box-work Thalassinoides (Th). The sharp-walled and unlined burrows are of irregular size and geometry, commonly with rounded terminations. The burrows are filled with marine sediment (light grey, black arrow), as well as by rhizogenic calcrete (dark grey, white arrow). Hammer in a is $32 \mathrm{~cm}$ long. c Bedding plane view of a Thalassinoides filled with laminated calcrete (black arrow). Coin diameter is $2.2 \mathrm{~cm}$. d Vertical section of irregularly branching (vertical, inclined, and horizontal) Thalassinoides burrows (black arrows) showing patchy distribution of calcretes inside the burrows (dark grey), which are passively filled with marine sediment (light grey). e-h Polished slabs representing vertical sections of irregularly branching Thalassinoides burrow systems as well as sub-circular cross sections (e), in which laminar rhizogenic calcretes (black arrows, rlc) occur intercalated with bioclastic packstone (bp) inside the burrows. White arrows in $\mathbf{e}, \mathbf{g}$, and $\mathbf{h}$ indicate patchy distribution of calcretes inside burrows, which probably indicates diagenetic overprint of bioclastic packstone. The primary substrate in which the burrows were excavated is bioclastic wackestone (bw)

\section{Materials and methods}

One well-exposed sedimentary section was measured at each of the study sites and facies attributes (e.g., structure, texture, microfacies), trace fossils, and subaerial exposure features were documented and described in detail (Fig. 2). Microfacies characteristics were analyzed from petrographic thin-sections according to Flügel (2004), and classified following Dunham (1962) and Embry and Klovan (1971). Trace fossils and subaerial exposure features associated with discontinuity surfaces were determined based on criteria summarized in Bromley (1975), Wright (1994), Clari et al. (1995), and Hillgärtner (1998), and were analyzed in the field, in polished hand-specimens (cut in various orientations), and in thin-sections. These analyses were supported by complementary investigations under a scanning electron microscope (SEM) using backscattered electron imaging (BSE) and energy dispersive $\mathrm{X}$-ray analysis (EDX). This semi-quantitative X-ray mapping was performed using a JSM 7000F Jeol with EDS at the Ruđer Bošković Institute (Zagreb, Croatia). Preparation for X-ray powder diffraction (XRPD) analysis included carbonate (calcite) fraction dissolution using acetic acid with an ammonium acetate $\left(1 \mathrm{~mol} \mathrm{dm}^{-3}\right)$ buffer of pH 5 (Jackson 1956). XRPD patterns were recorded for bulk samples and their insoluble residue using a Philips vertical X-ray goniometer (type X'Pert) equipped with a $\mathrm{Cu}$ tube at the Croatian Geological Survey (Zagreb, Croatia), with the following experimental conditions: $45 \mathrm{kV}, 40 \mathrm{~mA}$, PW 3018/00 PIXcel detector, primary beam divergence $1 / 4^{\circ}$, and continuous scan (step $0.02^{\circ} 2 \theta / \mathrm{s}$ ).

\section{Results}

Intraformational firmgrounds and composite surface

\section{Ichnological and sedimentological characterization of the discontinuities}

The lower part of the peritidal Coniacian to Santonian Gornji Humac Formation from the Šibenik locality is characterized by several intraformational discontinuities, namely the lower and upper firmgrounds as well as one composite surface (Fig. 2a). Stratigraphic location of these surfaces is well marked by distinct trace fossils and by facies differences between carbonate packages separated by these surfaces (Figs. 3, 4, 5). Only the lower firmground is characterized by an irregular morphology with up to $2 \mathrm{~cm}$ of relief (Fig. 3a, b). The marine trace fossils from all three discontinuities are represented exclusively by Thalassinoides. Burrow systems observed in vertical sections of the lower (Fig. 3a, b) and upper (Fig. 3e) firmgrounds as well as of the composite surface (Fig. 4d, e) penetrate 25 to $30 \mathrm{~cm}$ into the underlying strata. These systems typically comprise horizontal, inclined and vertical burrows (Figs. 3a, b, e, 4d, e), with mainly irregular (Figs. 3a, b, e, 4a, b, d-h) but also Y-shaped branching morphology (Fig. 3a, b), and burrows of irregular size and geometry within a single system (Figs. 3, 4). In addition, branching and interconnected burrows that form three-dimensional box-works are best observed along the bedding plane of the composite surface (Fig. 4a, b). In all three cases the burrows have well-defined, sharp, undeformed and unlined walls without pellets or bioglyphs (Figs. 3, 4), and circular to sub-circular cross sections (Figs. 3a, b, e, 4d, e). The burrow systems of the lower and upper firmgrounds are filled with sediment from the overlying beds (Fig. 3). The lower firmground burrows, excavated in bioclastic wackestone with miliolids, are occluded by bioclastic-lithoclastic fenestral wackestone with probable black pebbles (Fig. 3e, f) and with fenestrae filled with internal sediment and/or vadose silt (geopetal fill) and sparite (Fig. 3e, f). The upper firmground burrows, made in bioclastic mudstone to wackestone with Decastronema and miliolids, are filled with fenestral wackestone (Fig. 3c, d) showing similar features as the lower firmground.

The composite surface, with its firmground burrows produced in bioclastic wackestone with Thaumatoporella, Decastronema, and miliolids, is more complex. The first generation of sediment that passively filled the burrows is represented by bioclastic packstone (Figs. 4d-h, 5b, c), which is not present in the overlying bed and has the same biogenic components as the primary firmground substrate. The second type of trace fossils, which characterizes the 

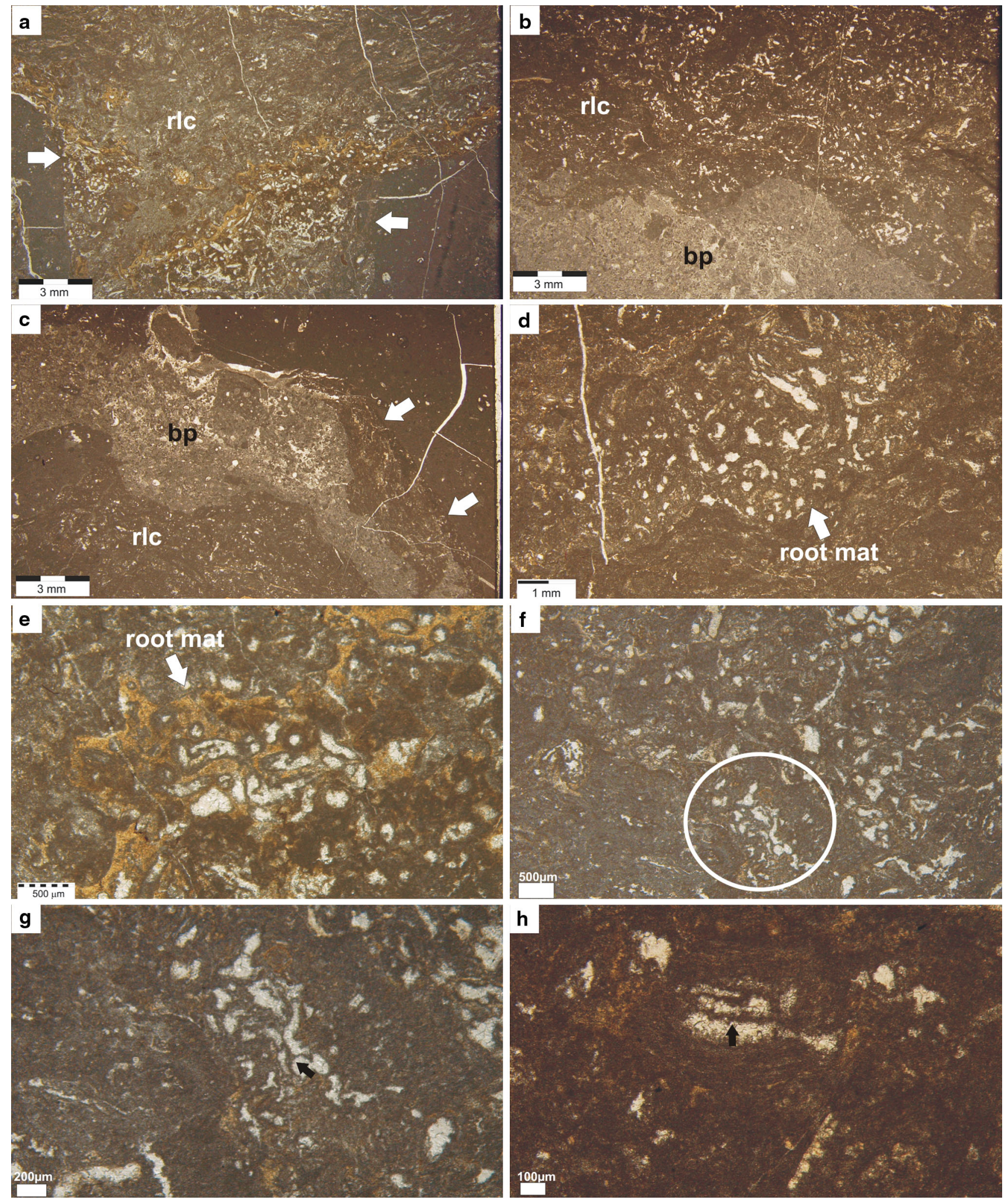

h

composite surface, is represented by laminar rhizogenic

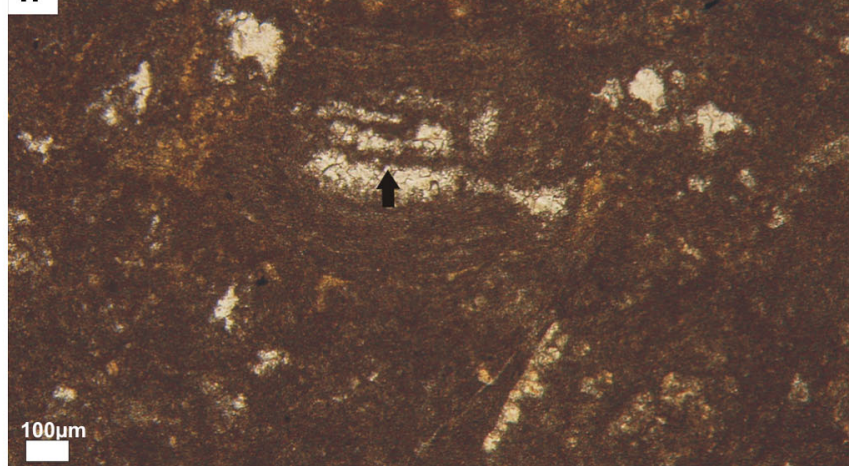
calcretes. They are represented by laminated fabric (Fig. 4c, f-h), with a submillimetric-to-millimetric microstructure of micritic laminae and tubular pores filled with

sparite which correspond to root tubules (Fig. 5a-e) (commonly coated by brownish sparite when observed in thin-sections; Fig. 5a, e). An alveolar-septal structure is very common inside the root tubules (Fig. 5f-h). These 
4 Fig. 5 Photomicrographs of features characterizing the composite surface recorded in the Gornji Humac Formation. a Thalassinoides in sharp contact with the surrounding bioclastic wackestone (white arrows) and infilled with laminar rhizogenic calcrete (rlc). b, c Intercalations of bioclastic packstone (bp) (with Thaumatoporella, Decastronema, and miliolids) and rhizogenic laminar calcrete (rlc) inside a Thalassinoides, which is in sharp contact with the surrounding bioclastic wackestone (white arrows in c). d, e Close-up view of laminar rhizogenic calcrete composed of submillimeter- to millimeter-sized microstructure of tubular pores (filled with sparite and coated with brownish sparite in e), interpreted as root tubules. f-h Well-developed alveolar-septal structure (black arrows) within root voids ( $\mathbf{g}$ is the close-up of encircled area in $\mathbf{f}$ )

calcretes developed only inside the firmground burrows, and their horizontal, sub-horizontal, and vertical orientations can be observed in outcrop (Fig. 4c, d), cut and polished slabs (Fig. 4e-h), and petrographic thin-sections (Fig. 5a-c). The calcretes commonly have a patchy distribution within the marine sediment that fills the burrows (Figs. 4e, g, h, 5b, c), or can also fill the entire burrow (Figs. 4c, f, 5a).

\section{Interpretation of the intraformational discontinuities and associated trace fossils}

The ichnogenus Thalassinoides Ehrenberg 1944 (Fig. 2a) consists of three-dimensional systems of cylindrical to elliptical burrows, mainly smooth-walled and of variable size (Rodríguez-Tovar et al. 2008). Several known Thalassinoides ichnospecies, as well as Thalassinoides tracemakers and behaviour, have been reviewed by Myrow (1995) and Rodríguez-Tovar et al. (2008 and references therein). Other trace fossils morphologically similar to Thalassinoides (such as Spongeliomorpha and Ophiomorpha), but with variations in burrow wall mainly as a result of changes in substrate consistency, are also well known (Myrow 1995; Bromley 1996). In addition, the ichnogenus Balanoglossites (Mägdefrau 1932), which is interpreted as a part of complex trace fossils comprising both burrow and boring components, occurs frequently in firmground and hardground substrates with sporadic epikarstic features (Knaust 2008; Knaust et al. 2012). Although Thalassinoides has been described from a variety of mainly marine (but also non-marine) environmental settings (see Rodríguez-Tovar et al. 2008 and references therein), this trace fossil is not a direct indicator of water depth, but is mainly related to other ecologic and sedimentologic factors, especially substrate character (Rodríguez-Tovar et al. 2008). Thalassinoides occurs in a range of sediment consistencies, and is common in well-oxygenated environments and soft but fairly cohesive substrates (Ekdale et al. 1984). Well-defined Thalassinoides is common in softgrounds as well as in firmgrounds (e.g., Pemberton et al. 2004), and has even been inferred to record emplacement during the first stages of hardground development (Ekdale and Bromley 1984; Ekdale 1992; Myrow 1995). Because sediment consistency explains some variations in burrow geometry within the ichnogenus Thalassinoides (Myrow 1995), different Thalassinoides ichnospecies have been interpreted to occur in different substrate consistencies, with Thalassinoides suevicus present in softgrounds and Thalassinoides paradoxicus in firmgrounds (Savrda et al. 2001).

Thalassinoides paradoxicus Woodward, which corresponds to branching and box-work burrow systems of highly irregular geometry and size (Kennedy 1967; Bromley 1975; Myrow 1995; Rodríguez-Tovar et al. 2008; Schwarz and Buatois 2012), is interpreted here to mark the firmgrounds (Fig. 3) and composite surface (Figs. 4, 5) recorded in the Gornji Humac Formation at the Šibenik locality. According to Bromley (1975), Thalassinoides is the only ichnotaxon in the omission suite of trace fossils associated with omission surfaces (see also Savrda 2012). Based on the presence of sharp and unlined walls, passive fill with sediment from the overlying beds, vertical to subvertical domichnia, and lack of compaction, the burrows are attributed to the substrate-controlled Glossifungites ichnofacies (Pemberton et al. 2004; MacEachern et al. 2007; Buatois and Mángano 2011; Schwarz and Buatois 2012; Knaust et al. 2012; Savrda 2012) and are interpreted to have been excavated in a firmground. The lack of evidence for pre-omission trace fossil suites associated with the discontinuities described here, such as the softground Thalassinoides suevicus burrows, may be due to the softground burrows being cross-cut by burrows of firmground Thalassinoides paradoxicus (Bromley 1967, 1975; Myrow 1995; Savrda 2012), and possibly even completely overprinted (Christ et al. 2012).

Laminar calcretes that developed into Thalassinoides and are diagenetically overprinting marine deposits (e.g., Rossinsky et al. 1993; Alonso-Zarza and Jones 2007) (probably more favorable un-consolidated substrate and possible empty spaces left within burrows; see Rasmussen and Neumann 1988), which passively filled the burrows of the composite surface (Figs. 4, 5), are root-related and produced by calcification in and around root mats (extracellular calcification) (Wright et al. 1988). This is indicated by their fabric with a millimeter-to-submillimeter microstructure of micritic laminae and tubular pores (root tubules) with alveolar-septal structure (Fig. 5). Such calcretes are therefore regarded as rhizogenic (Wright et al. 1988; Alonso-Zarza and Wright 2010 and references therein). According to the firmground burrows and subsequently developed rhizogenic calcretes, the surface characterized by these features developed through both submarine firmground and subaerial exposure stages, and is therefore defined as a composite (polygenic) surface (sensu Sattler et al. 2005; Rameil et al. 2012). In addition, the 
lower firmground surface described from the Šibenik locality could also represent a composite surface, based on the presence of probable black pebbles from the overlying strata which passively filled the burrows (Fig. 3). Black pebbles are commonly (but not exclusively) interpreted as indicators of subaerial exposure (Strasser 1984). The local or regional/global character of these surfaces based on their lateral extent (Di Stefano et al. 2002; Flügel 2004; Sattler et al. 2005; Brlek et al. 2012; Schwarz and Buatois 2012), as well as any possible lateral variability (Sattler et al.
2005; Schwarz and Buatois 2012) has yet to be established through detailed geological mapping of the study area.

\section{Regional Cretaceous to Paleogene (K-Pg) subaerial unconformity}

Subaerial exposure features, including biogenic calcretes with rhizoliths, laminar calcretes and pisoids, as well as paleokarst (see below), were recorded in the uppermost part of both the Coniacian to Santonian Gornji Humac
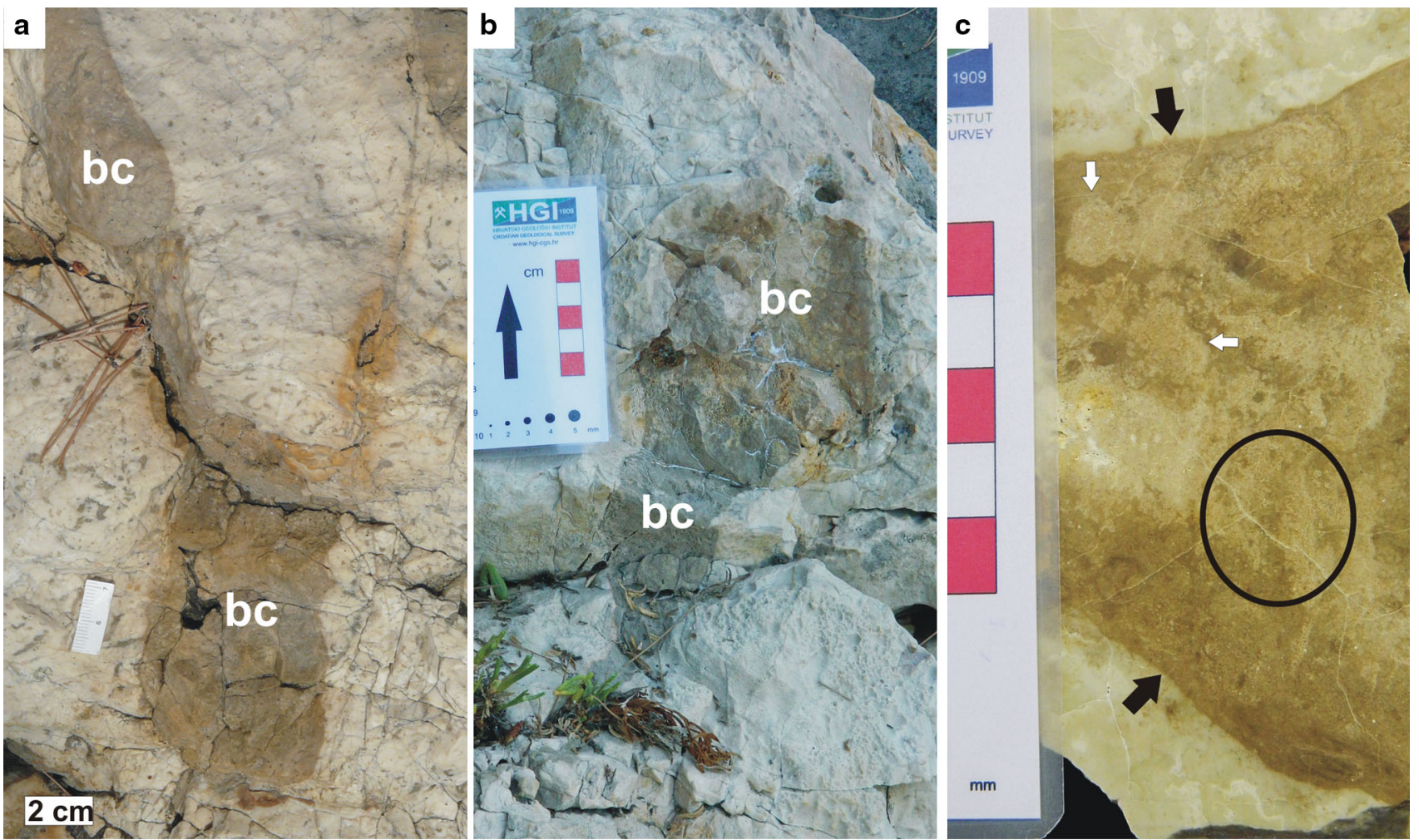

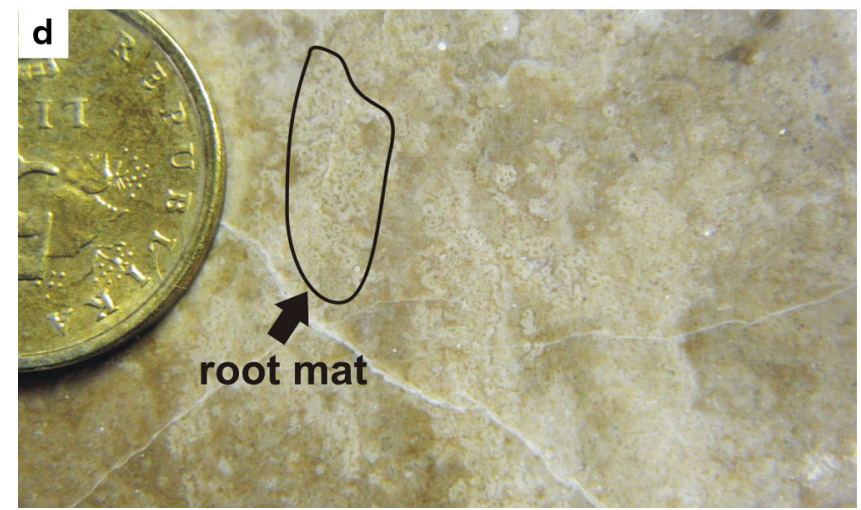

Fig. 6 Field exposure $(\mathbf{a}, \mathbf{b}, \mathbf{e})$ and polished slabs $(\mathbf{c}, \mathbf{d})$ of the first type of biogenic calcretes within marine limestones of the Gornji Humac Formation (Šibenik locality) marking a regional subaerial unconformity. a, b Brownish biogenic calcrete (bc) occurring as irregular patches (oriented here perpendicular to bedding) within marine limestones. c Polished slab showing biogenic calcrete with

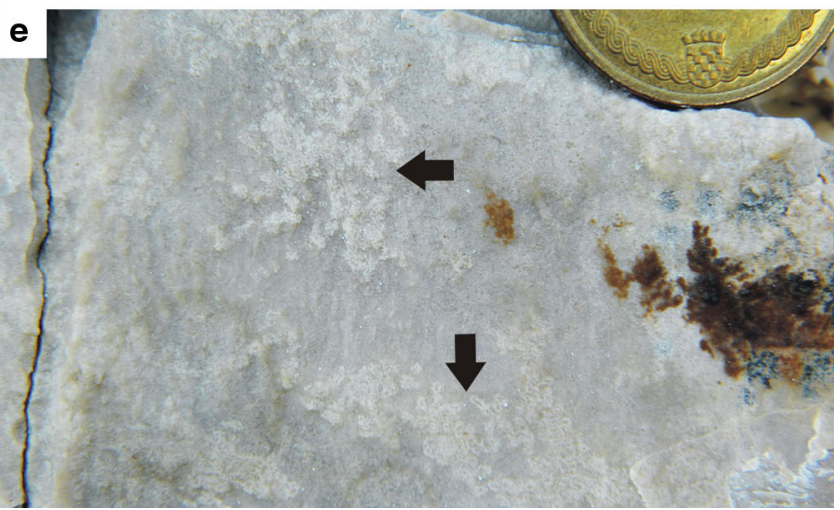

numerous rhizoliths present in bundles (white arrows). Calcrete diagenetically overprints and is in sharp contact (black arrows) with marine limestone. Scale in $\mathrm{cm}$. d Close-up of the encircled area in c showing numerous rhizoliths that represent a root mat. Coin diameter: $1.7 \mathrm{~cm}$. e Field view of rhizoliths (black arrows). Coin diameter: $1.7 \mathrm{~cm}$ 
Formation (Šibenik locality; Fig. 2a) and the Upper Maastrichtian to Paleocene Sumartin Formation (Hvar locality; Fig. 2b), and characterize the regional K-Pg subaerial unconformity. These successions are unconformably overlain by transgressive Eocene carbonates (Kozina beds) (Fig. 2).

\section{Characterization of biogenic calcretes}

Calcretes in the Gornji Humac Formation (Šibenik locality) were observed in the field as irregular, brownish and whitish patches within peritidal limestones (Fig. 6a-c), which extend to about $10 \mathrm{~m}$ below the unconformity (Fig. 2a).
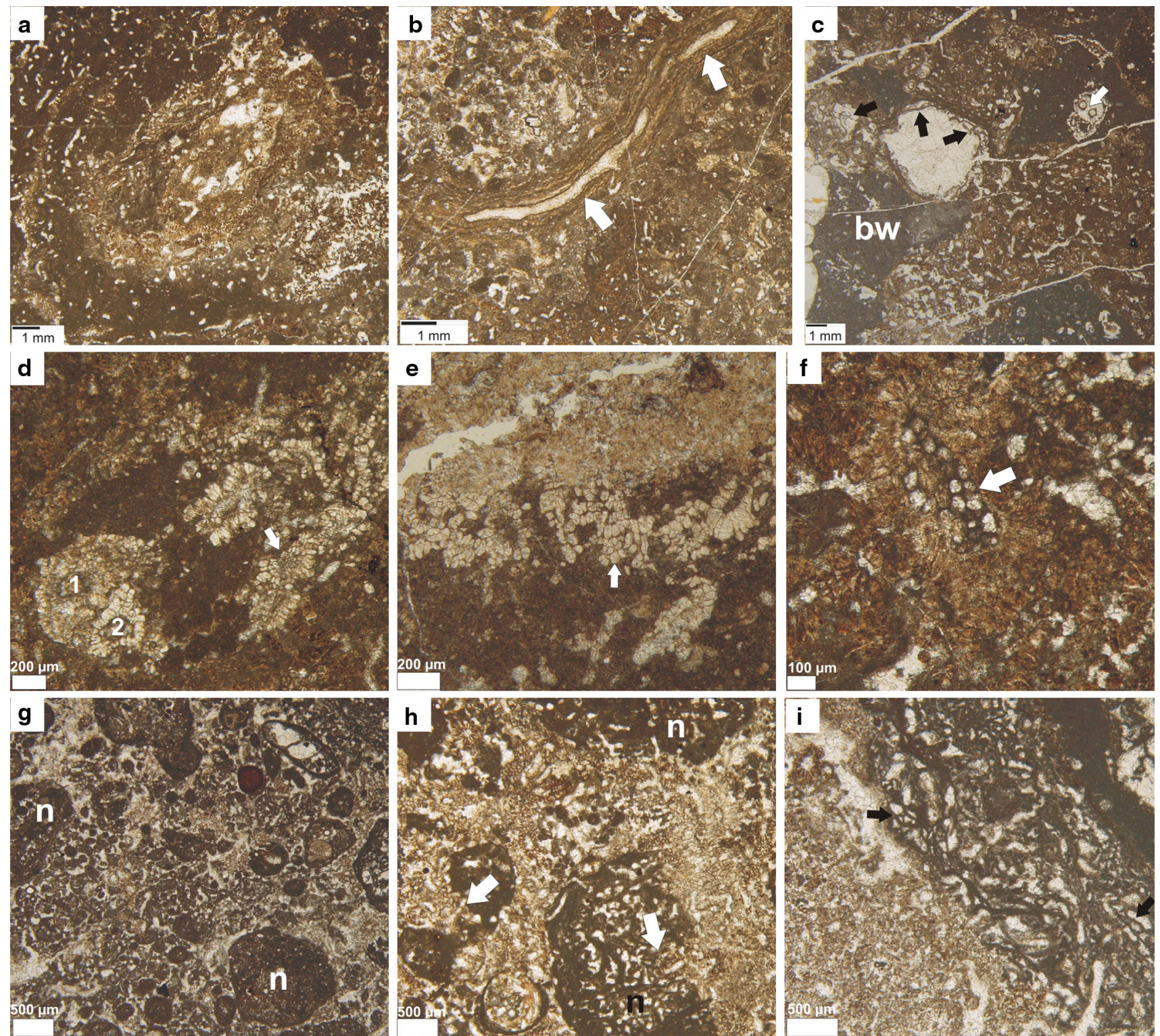

Fig. 7 Photomicrographs of features characterizing the first type of biogenic calcrete from the Gornji Humac Formation. a Biogenic calcrete with micritic matrix and numerous rhizolithic structures represented by root moulds, root tubules, and Microcodium aggregates (see text). b Oblique section of root tubule(s) (white arrows) composed of sparite-filled voids with crude concentric micritic and microsparitic coatings. c Biogenic calcrete, developed within bioclastic wackestone (bw), with root tubules characterized by welldeveloped alveolar-septal structure (black arrows) and micritic cylinders (white arrow). d, e Microcodium aggregates (see text) consisting of multiple (white arrows) and single layers of isodiametric and slightly elongated brownish and whitish calcite crystals commonly surrounding voids filled with sparite ( 1 and 2 in d). f Partly permineralized root formed by impregnation of lignified cellular tissue (multiple layers of isodiametric cells) with clear sparite cement (white arrow). g, h Nodular fabric of calcrete caused by root penetration and calcification, with Microcodium aggregates present between nodules (n) and overprinting primary homogeneous calcrete fabric (white arrows). i Biogenic calcrete with well-developed alveolar-septal structure (black arrows) 

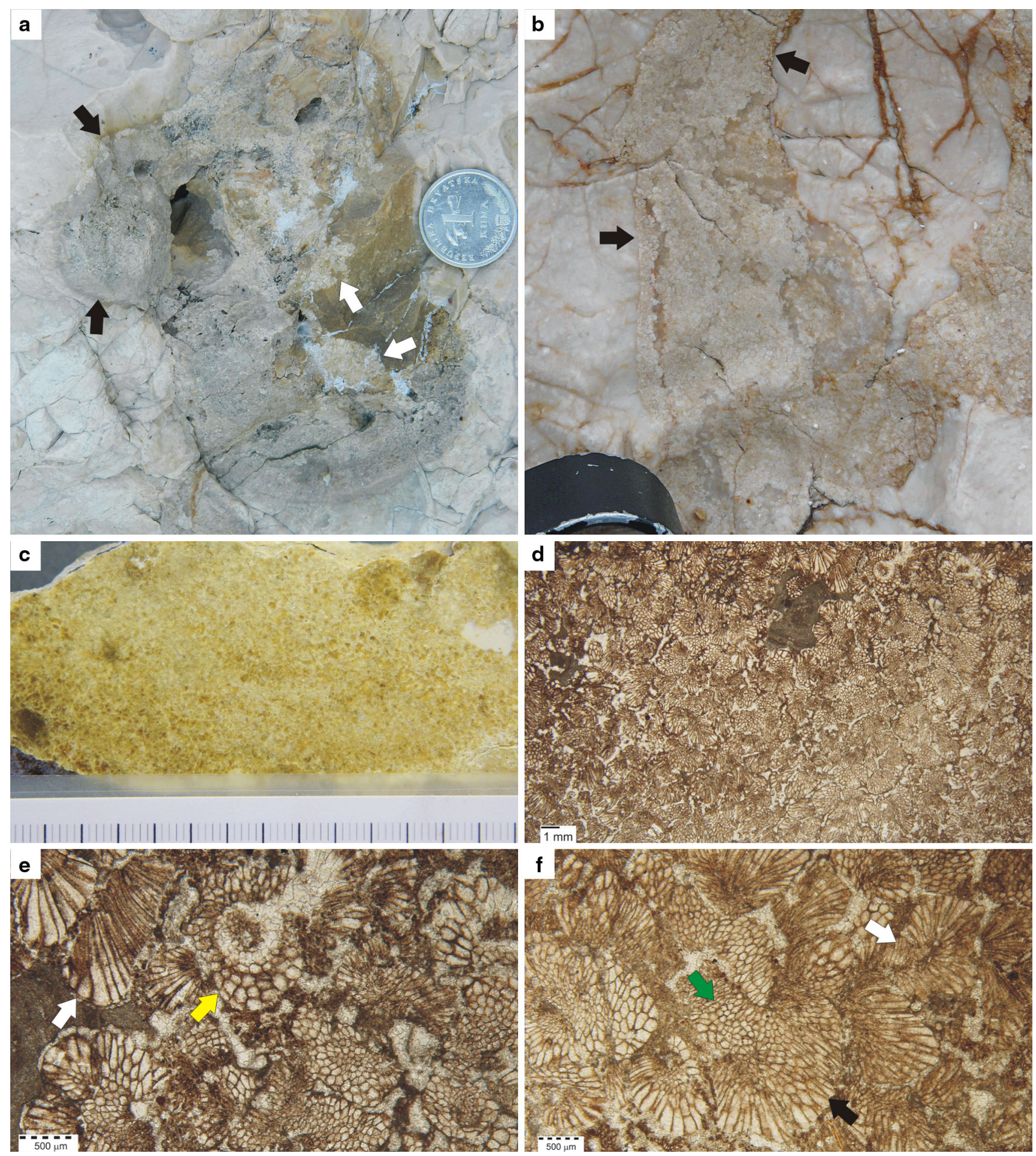

Two types of calcrete (calcitic composition) were observed, with regard to their dominant biogenic components.

The first type (brownish patches; Fig. 6a-c) is represented by various biogenic components, including rhizoliths (sensu Klappa 1980) (Figs. 6d, e, 7a), embedded in the surrounding micritic matrix. Microcodium aggregates are represented by multiple and single layers of mostly isodiametric and slightly elongated brownish and whitish calcite crystals that commonly surround voids filled with sparite (Fig. $7 \mathrm{~d}-\mathrm{f}$ ), and are mainly present in bundles (rarely isolated), defining root mats (Fig. 6d, e). Recorded root tubules are composed of sparite-filled voids with crude concentric micritic and microsparitic coatings (Fig. 7b, c), with commonly well-developed alveolar-septal structures 
4 Fig. 8 Characteristics of the second type of biogenic calcrete with rhizoliths within marine limestones of the Gornji Humac Formation (a, c-f) and its lateral stratigraphic equivalent on Ravni Žakan Island in the Kornati archipelago (Adriatic Sea) (see text) (b) representing a regional subaerial unconformity. a-d Field exposure (a, b), polished slab (c), and photomicrograph (d) of the second type of biogenic calcrete composed entirely of Microcodium aggregates. The calcrete is in sharp contact with the primary marine limestones (black arrows in $\mathbf{a}$ and $\mathbf{b}$ ) and can be associated with the first type of biogenic calcrete (white arrows in a). Coin diameter in $\mathbf{a}$ is $2.2 \mathrm{~cm}$. Hand lens diameter in $\mathbf{b}$ is $2.5 \mathrm{~cm}$. e, f Photomicrographs representing close-up view of $\mathbf{d}$ with typical laminar (white arrow in $\mathbf{e}$ ) and cylindrical (white arrow in f) Microcodium aggregates and other Microcodium aggregates. Some of these structures may possibly represent calcified roots with multilayered cells (yellow arrow in e), as well as possible transitional forms between multilayered isodiametric calcified root cells (green arrow in f) and typical single-layered Microcodium aggregates with elongated calcite prisms (black arrow in f) (see text)

and micritic cylinders inside sparite-filled voids (Fig. 7c, i). Microcodium aggregates are also present between isolated calcrete nodules (Fig. 7g-i). The second calcrete type (whitish patches and "veins") (Fig. 8a: Šibenik locality; Fig. 8b: Ravni Žakan Island, see above) is composed entirely of rhizoliths (sensu Wright et al. 1995; Košir 2004) (Fig. 8c, d). This calcrete is represented by typical Microcodium aggregates (sensu Košir 2004), including laminar (Fig. 8e), cylindrical (Fig. 8f), and spheroidal morphotypes.

\section{Interpretation of biogenic (beta microfabric) calcretes with rhizoliths}

Biogenic or beta microfabric calcretes (sensu Wright and Tucker 1991) are common in carbonate-rich substrates (Wright 1994, 2007) and are well-developed beneath the regional subaerial unconformity in the Gornji Humac Formation at the Šibenik locality (Fig. 2a), where they exhibit a very diverse range of textures of biogenic, mainly root-related and fungal (e.g., alveolar-septal structure) origins (Figs. 6, 7, 8). Such calcretes have been previously documented elsewhere and reviewed by many authors (Wright and Tucker 1991; Wright 1994; Alonso-Zarza 2003; Košir 2004; Wright 2007; Alonso-Zarza and Wright 2010). Rhizoliths (sensu Klappa 1980), including root tubules, calcified root cells and Microcodium aggregates, represent one of the most prominent features in biogenic calcretes (Jaillard et al. 1991; Wright 1994; Wright et al. 1995; Alonso-Zarza et al. 1998; Alonso-Zarza 1999; Košir 2004). Two end-member rhizolithic structures, owing their origin to calcification of root cells (intracellular calcification), have been described in the literature (Košir 2004). Calcified root cells are represented by a multilayer arrangement of isodiametric cells (Jaillard et al. 1991; Košir 2004), while the typical Microcodium aggregates are composed of a single layer of individual, elongated pyramidal or prismatic crystals of calcite (Košir 2004). In addition, intermediate morphologies that prove a rhizogenic origin of typical Microcodium are also known (Košir 2004; see also Kabanov et al. 2008), as well as atypical Microcodium type b aggregates (Alonso-Zarza et al. 1998). The current study did not include a detailed investigation of these complex morphological differences and therefore these structures are generally referred to here as Microcodium aggregates (e.g., present in the first type of biogenic calcretes described herein; Fig. 7). The presence of the most typical and unequivocal structures, such as typical Microcodium aggregates (including typical corn-cob, spherulitic and laminar morphotypes), present, for example, in the second type of biogenic calcretes described here (Fig. 8) is also noted. In situ Microcodium aggregates, which constitute the dominant fabric of the second type (Fig. 8; type 1 rhizogenic calcretes sensu Wright et al. 1995) of biogenic calcretes in the Gornji Humac Formation, indicate subaerial exposure and pedogenic modification of carbonate successions (Esteban and Klappa 1983; Wright 1994; Košir 2004).

\section{Characterization of laminar calcretes and pisoids}

Yellowish and reddish laminar calcretes and pisoids penetrate the Sumartin Formation (Hvar locality) to a depth of about $10 \mathrm{~m}$ below the unconformity (Fig. 2b). Laminar calcretes (commonly oriented vertically to host substrate; Fig. 9a, b, d) and pisoids have various types of relationships within the overall calcrete fabric, but most commonly laminar calcretes are found in the outer part of the fabric where they coat contacts with the host limestone, and pisoids occur in the inner parts (Fig. 9a, b, d). Laminar calcretes of calcitic composition are characterized by an overall dome-shaped (with domes up to $1 \mathrm{~cm}$ thick and occasionally even thicker; Fig. 9b, d, e) laminar fabric with several components, including dense and crudely laminated micrite with probable root tubules, rare alveolar-septal structure, and coated grains/peloids. The dome-shaped fabric is also composed of sparite with massive appearance and common Microcodium aggregates. Pisoids (coated grains) (mainly sand sized, but also larger including composite grains, and well rounded) have nuclei that are crudely coated with one to several predominantly symmetric, but also asymmetric, dense micritic coatings (similar to laminar calcretes) with randomly distributed non-carbonate material (Fig. 9e, f). Pisoid nuclei are mostly composed of yellowish and reddish bauxitic material (mixture of kaolinite, boehmite, goethite, hematite; Figs. 9c-f, 10a, b), but also of carbonate (e.g., Microcodium aggregates). Red coloration of some pisoids (Fig. 9b, d) is caused by the presence of hematite (Figs. 9f, 10b), while pisoids with no hematite (Fig. 10a) have yellowish coloration (Fig. 9a, c). 

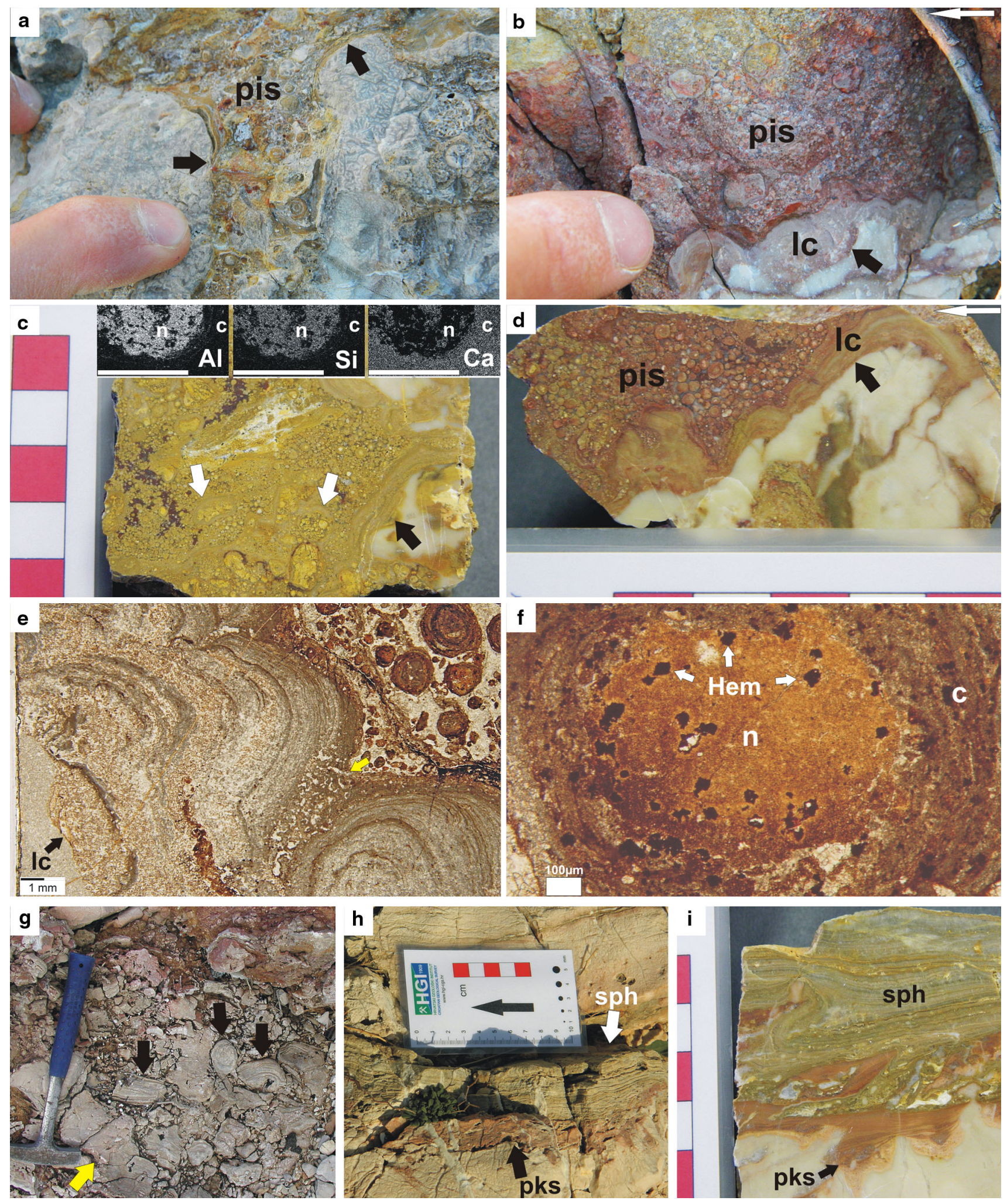

The same bauxitic material (partly calcretized with nodularization) that forms the pisoid nuclei was also recorded in massive accumulations, i.e., solution pits, in the lower parts of the subaerially exposed succession (Fig. 2b). Lateral variability in the development of subaerial exposure features, however, was recorded in the Hvar locality. In some profiles pure bauxitic deposits, which were not overprinted by calcretes, are present throughout the entire subaerially 
4 Fig. 9 Characteristics of the subaerial exposure features within marine limestones of the Sumartin Formation (Hvar locality) representing a regional subaerial unconformity. a-d Exposures (a, b) and polished slabs (c, d) of yellowish and reddish laminar calcretes and pisoids. Laminar calcretes (lc) are present at the contact between the marine host limestone and the overall calcrete fabric (black arrows), and also coat larger bauxitic nodules (large white arrows in c), while pisoids (pis) occur in the inner part of the fabric. Elemental maps for $\mathrm{Al}, \mathrm{Si}$ and $\mathrm{Ca}$ on photograph $\mathbf{c}$ indicate that the nuclei (n) of pisoids (such as the one in f) are composed of bauxitic material, while the pisoid coating (c) is composed of calcite (bright areas correspond to high content of a certain element). White arrows in $\mathbf{b}$ and $\mathbf{d}$ indicate stratigraphic "up" orientation of the sample. e Photomicrograph showing the dome-shaped laminar calcrete (lc) fabric composed of alternating layers of dense and crudely laminated micrite with root tubules (yellow arrow) and brownish sparite crystals containing Microcodium aggregates. Pisoids can be observed in the upper right corner. f Photomicrograph showing a pisoid composed of bauxitic nucleus (n) with mostly opaque hematite grains (reddish pisoids such as the ones in $\mathbf{b}$ and $\mathbf{d}$ ), and the coating (c) made up mainly of crudely laminated micrite and microsparite. g Field photograph of a clastsupported breccia composed of resedimented speleothem (black arrows) and angular marine limestone (yellow arrow) clasts of various orientation. Hammer is $32 \mathrm{~cm}$ long. h, i Field photograph (h) and polished slab (i) of in situ speleothems (sph) (likely flowstones) and associated reddish paleokarstic sediment (pks)

altered part of the Sumartin Formation. Calcretes associated only with the host limestone were recorded as well.

\section{Interpretation of laminar calcretes and pisoids}

Formation of laminar calcretes, such as those recorded beneath the regional subaerial unconformity in the $\mathrm{Su}$ martin Formation at the Hvar locality (Figs. 2b, 9), may be the result of calcification of horizontal and vertical root mats (Wright et al. 1988, 1995; Alonso-Zarza 1999; Alonso-Zarza and Jones 2007). Consequently, such calcretes are referred to as rootcretes or rhizogenic calcretes (sensu Wright et al. 1995). Laminar calcretes from Hvar, represented by a columnar structure partially build of alternating micritic layers with probable root tubules as well as layers with Microcodium aggregates (Fig. 9), may partly owe their origin to root mat calcification. However, because laminar calcretes may be of polygenic nature, other organisms, such as cyanobacteria, bacteria, fungi, and lichens (Jones and Kahle 1985; Jones 1994; Alonso-Zarza and Jones 2007; Zhou and Chafetz 2009; Meléndez et al. 2011), may have also contributed to carbonate precipitation in these calcretes. For example, thinly laminated micritic layers resemble the microstromatolite of Jones and Kahle (1985) and Jones (1994). Similar processes of carbonate precipitation may have contributed to formation of the pisoid coating recorded at the Hvar locality. These coatings have similar composition (mostly dense micrite) as laminar calcretes with which they are associated (Fig. 9) (AlonsoZarza and Jones 2007; Wright 2007; Zhou and Chafetz
2009). Development of associated laminar calcretes and pisoids is partly related to the observed alteration of the marine host limestone and bauxitic (see Bardossy 1982) deposits (Figs. 9, 10), which is indicated by bauxite grains commonly forming nuclei of coated grains/pisoids (Fig. 9). Laminar calcretes that develop inside primary karstic voids and partly penetrate and diagenetically alter the host rock, as well as the processes responsible for the formation of associated pisoids, have been previously documented from the geological record (Rossinsky et al. 1993; Wright 1994; Durand et al. 2006; Alonso-Zarza and Jones 2007; AlonsoZarza and Wright 2010; Armenteros 2010; Durand et al. 2010). Although calcretes may be much younger than the strata within which they develop (Rossinsky et al. 1993; see also Immenhauser and Rameil 2011), calcretes from the Gornji Humac and Sumartin formations described here, are interpreted as older than the transgressive marine Paleogene beds which unconformably overlie the Upper Cretaceous to Paleogene successions at the study sites (Fig. 2). These correlative subaerial exposure surfaces developed in response to the early stage of Dinaridic orogeny (Korbar 2009), and have also been reported from other Upper Cretaceous Adriatic-Dinaridic Carbonate Platform (ADCP) successions (see below; Otoničar 2007; Brlek et al. 2012). Possible paleoclimatic (and geomorphological) reconstructions (Wright 1994; D’Argenio and Mindszenty 1995; Miller et al. 2012) based on stratigraphic and spatial relationships between various subaerial exposure features recorded at the Hvar locality require further petrological and geochemical analysis, as well as detailed geological mapping. In the example studied here, in which calcretization of bauxitic deposits took place as evidenced by bauxite material in nuclei of calcrete pisoids (Fig. 9), it is obvious that the observed calcretes are younger than the bauxitic deposits they overprint. This may indicate a transition from more humid (i.e., high temperatures and intense leaching necessary for bauxite formation) to more arid (since at least semi-aridity is necessary for calcrete formation) paleoclimatic conditions during subaerial exposure (Wright 1994; D'Argenio and Mindszenty 1995). However, the possibility that bauxitic material may have formed elsewhere and was transported mechanically (e.g., aeolian transport) to the subaerially exposed environment (Herwitz et al. 1996) should also be considered. In addition, a possibility that different paleoclimatic conditions may have existed contemporaneously in the Mediterranean region during the Cretaceous to Paleogene time interval should also be taken into account (e.g., Bravi et al. 2008).

\section{Characterization of paleokarst}

Surface and subsurface paleokarst related to the regional subaerial unconformity was recorded in the Sumartin 
Formation (Hvar locality). Surface paleokarstic features mainly correspond to subcutaneous karst i.e., fissures and small closed depressions enlarged by dissolution filled with bauxite and calcrete material. In contrast, an interval up to $2 \mathrm{~m}$ thick (former cave) (Fig. 2b) (with variable lateral thickness) characterized by clast-supported breccias with rounded and angular clasts of resedimented speleothems and marine limestones (Fig. 9g) represents subsurface paleokarst. In situ speleothems (i.e., flowstones, calcite rafts) associated with reddish paleokarstic sediment were also recorded (Fig. 9h, i).

We also recorded possible paleokarstic features (e.g., speleothems) within the Gornji Humac succession at the Šibenik locality. However, due to limited lateral exposure these features require further investigation (e.g., detailed geological mapping) to be unequivocally identified as paleokarst.

\section{Discussion}

Implications of intraformational discontinuities for sequence stratigraphy

Substrate-controlled ichnofacies (Glossifungites and Trypanites ichnofacies) are highly applicable to carbonate sequence stratigraphy (see reviews in Rodríguez-Tovar et al. 2007; Buatois and Mángano 2011; Schwarz and Buatois 2012). The factors which might be involved in marine firmground and hardground formation were reviewed by Rodríguez-Tovar et al. (2006), Schwarz and Buatois (2012) and Savrda (2012). In carbonate-rich environments, firmground development and subsequent colonization is mainly controlled by the cessation of sedimentation (Gruszczynski et al. 2002; Rodríguez-Tovar 2005; Rodríguez-Tovar et al. 2006 and references therein), while erosion is principally (but not exclusively; Schwarz and Buatois 2012; Savrda 2012) related to siliciclastic substrates (Rodríguez-Tovar et al. 2006).

The two firmgrounds recorded in this study are characterized by the homogeneity of sediments that passively infilled the burrows and by the lack of abundant eroded carbonate intraclasts (Schwarz and Buatois 2012) in the strata immediately overlying the two firmgrounds or in the firmground burrows. These characteristics indicate the absence of exhumation or marine erosional processes, and phase of omission between the formation of Thalassinoides and deposition of the overlying strata (Rodríguez-Tovar 2005; Rodríguez-Tovar et al. 2006). This suggests that the firmgrounds must be mainly related to cessation of precipitation and/or deposition of calcium carbonate. Such omission surfaces involve very little or no erosion and are considered minor discontinuity surfaces (Bromley 1975;
Kennedy and Garrison 1975). In some instances, their early marine incipient cementation may be related to rapid firmground generation (Rodríguez-Tovar et al. 2006 and references therein). The absence of high-energy deposits (e.g., inner ramp settings) associated with the analyzed firmgrounds at the Šibenik locality indicates that the process of sea-water forcing through sediments by strong currents, which would favor early cementation and sediment stiffness (Schwarz and Buatois 2012 and references therein), was not active. Although other possible mechanisms for early carbonate cementation of marine sediments and firmground formation have also been proposed (Rodríguez-Tovar et al. 2006 and references therein; Knaust et al. 2012; Savrda 2012), no unequivocal conclusions concerning the genesis of the two analyzed firmgrounds can be reached here. In addition, we do not exclude the possibility of rapid firmground genesis and colonization by Thalassinoides tracemakers, followed by rapid burial (Rodríguez-Tovar 2005; Rodríguez-Tovar et al. 2006). The deposits that overlie the lower and upper firmgrounds and also passively filled the firmground burrows at the Šibenik locality are characterized by various features indicating intertidal/supratidal depositional environments (Tucker and Wright 1990; Flügel 2004), such as black pebbles, fenestral fabrics, and geopetal fill with internal sediment and/or vadose silt (Fig. 3). This indicates a transition (shallowing) from shallow subtidal environments (absence of intertidal/ supratidal features, but presence of cyanobacteria and calcareous green algae; Flügel 2004) below the discontinuities to intertidal/supratidal environments above the discontinuities. Although marine discontinuities developed during periods of sea-level fall commonly owe their origin to extensive erosional exhumation (Christ et al. 2012; Schwarz and Buatois 2012), we suggest that the relative sea-level fall as evidenced by the shallowing of facies across the two firmgrounds caused a phase of omission (involving very little or no erosion), which produced the two firmgrounds. We realize, however, that this model may be too simplistic because interactions among various factors might also contribute towards discontinuity formation (Sattler et al. 2005; Rodríguez-Tovar et al. 2006; Christ et al. 2012; Schwarz and Buatois 2012; Savrda 2012).

The composite surface (Figs. 4, 5) first started developing through a submarine firmground stage represented by Thalassinoides burrows of the Glossifungites ichnofacies, which are passively filled with shallow subtidal sediment not present in the overlying strata. This indicates recurrent stages of deposition and erosion (Hillgärtner 1998; Cachão et al. 2009). The presence of shafts, defined as vertical burrows or vertical elements of a burrow system (Frey 1973; Bromley 1996), commonly indicates the absence of significant erosion, which might lead to firmground conditions (Rodríguez-Tovar et al. 2006; see also Schwarz and 


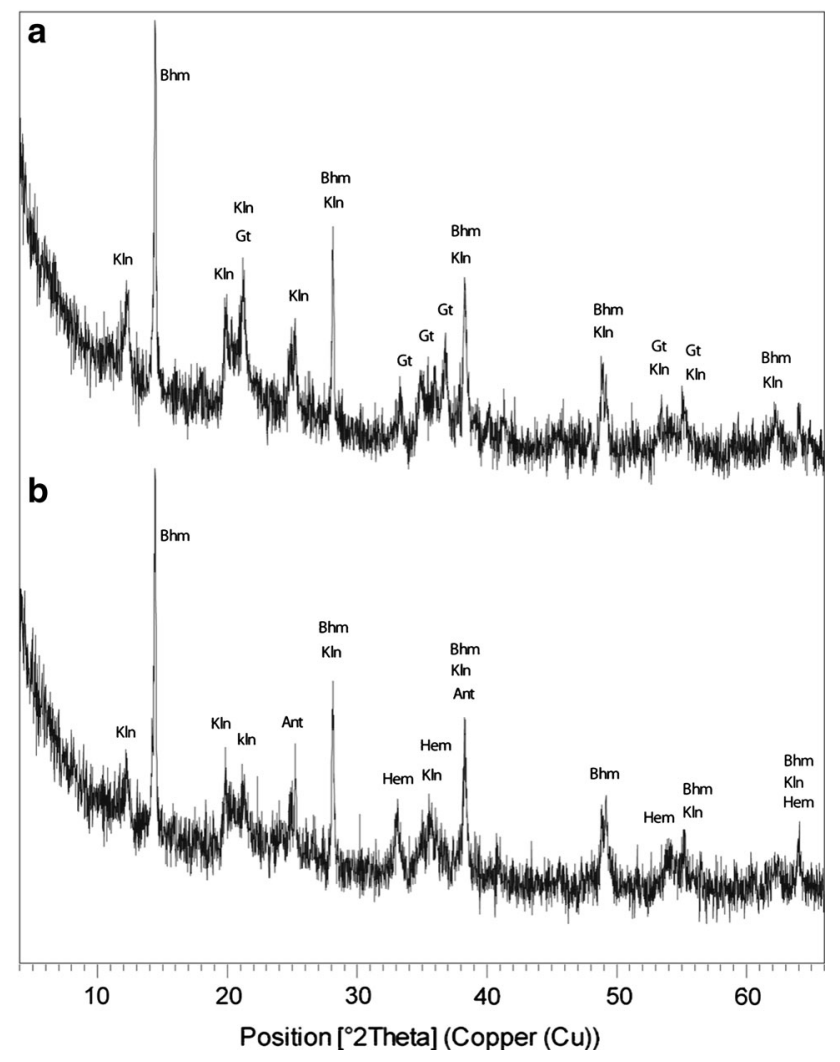

Fig. 10 XRD patterns of insoluble residue of samples a and b representing yellowish and reddish calcrete pisoids, respectively, from the Sumartin Formation. Insoluble residues show composition typical of karst bauxites. Kln kaolinite, Bhm boehmite, Gt goethite, Hem hematite, Ant anatase

Buatois 2012). In addition, determination of precise relationships between shafts and sediment infills helps to evaluate the importance of erosion or the recognition of several possible phases of erosion (Rodríguez-Tovar pers. comm.). These data may aid in reconstruction of relative sea-level fluctuations, which might have affected the recorded composite surface. Although we observed individual vertical elements of the boxwork Thalassinoides associated with the composite surface (Fig. 4) as well as with the two firmgrounds (Fig. 3), due to outcrop limitations we cannot unequivocally confirm the presence of vertical shafts. In addition, the first generation of burrow fill represented by marine sediments was subsequently partly overprinted by rhizogenic calcretes (Figs. 4, 5), which obscured the primary relationships between burrows and marine sediment fill. Therefore, the precise role and importance of erosion or several erosional events in the genesis of the composite surface remain to be determined. Future investigations (including detailed geological mapping of the area) may give answers to whether sediment stiffness required for firmground formation was achieved by erosion, possibly due to a relative sea-level fall
(Schwarz and Buatois 2012), or by omission involving little or no erosion (Rodríguez-Tovar et al. 2006). Incipient lithification of the sediment during tracemaker activity are suggested by the observed irregular and boxwork geometry of Thalassinoides burrows in the composite surface. However, the exact mechanism(s) (see Rodríguez-Tovar et al. 2006 and references therein; Knaust et al. 2012; Savrda 2012), which might have triggered possible lithification remain to be investigated. Subsequent subaerial exposure of the submarine firmground, which resulted in formation of the composite surface (development of rhizogenic laminar calcretes inside firmground burrows), indicates that the surface was modified during subsequent relative sea-level fall (i.e., allogenic forcing; Hillgärtner 1998; Sattler et al. 2005). This indicates that the composite surface may have experienced several stages of transgression and regression (Wilson et al. 1998; Sattler et al. 2005; Cachão et al. 2009; Rameil et al. 2012), which may have removed portions of the underlying rock record (Hillgärtner 1998; Sattler et al. 2005; Cachão et al. 2009; Rameil et al. 2012). Eustatic sea-level changes (e.g., Wilson et al. 1998) and combined effects of tectonics, eustasy, and/or productivity perturbations (e.g., Di Stefano and Mindszenty 2000) may have been responsible for the formation of the composite surface. More work is needed, however, to further tease out these various possibilities. Our findings so far exemplify how detailed documentation of substratecontrolled ichnofacies and calcrete features may reveal a great complexity of hiatal surfaces in shallow-marine carbonate successions (Rameil et al. 2012).

Tectonostratigraphic framework of the regional subaerial unconformity

Stratigraphy of the Adriatic-Dinaridic carbonate platform (ADCP) and the orogenic evolution of the external Dinarides are closely related and are the subject of an ongoing debate concerning the Mesozoic paleogeography of the region (Korbar 2009). According to Korbar (2009), the ADCP domain (also called Adriatic Carbonate Platform sensu Vlahović et al. 2005) is separated into the Adriatic and Dinaridic segments, with the Coniacian to Santonian Gornji Humac Formation from the Šibenik locality belonging to the Dinaridic SW tectonostratigraphic unit (High Karst), and the Maastrichtian to Paleocene Sumartin Formation at the Hvar locality to the Adriatic NE tectonostratigraphic unit (Dalmatian Karst). These tectonostratigraphic units are regionally characterized by different stratigraphic development (Korbar 2009; Fig. 2).

The subaerial exposure surfaces from the uppermost parts of the Gornji Humac and Sumartin formations at the Sibenik and Hvar localities, respectively, represented by biogenic calcretes, paleokarst (sensu Esteban and Klappa 
1983; James and Choquette 1988), and bauxites, have also been recorded in other ADCP Cenomanian to Maastrichtian successions, which are unconformably overlain by Paleogene transgressive marine deposits (Ćosović et al. 2004; Steuber et al. 2005; Vlahović et al. 2005; Otoničar 2007; Korbar 2009; Brlek et al. 2012). In Istria, however, the successions that directly underlie the related subaerial unconformity could be as old as Valanginian (Matičec et al. 1996), while locally in SW Slovenia the oldest deposits that overlie the same subaerial exposure surface belong to the Maastrichtian (Otoničar 2007). Stratigraphic gaps along these surfaces are in the order of several My in duration and are commonly marked by well-developed paleokarstic horizons and bauxitic deposits (Šinkovec 1973; Sakač and Šinkovec 1991; Otoničar 2007; Kovačević Galović et al. 2012), which reflect significant environmental changes in response to regional to global, long-term processes of tectono-eustatic origin (Clari et al. 1995; D’Argenio and Mindszenty 1995; Hillgärtner 1998). The Late Cretaceous to Paleogene regional emergence phase of variable duration on different parts of the ADCP was caused by very extensive Late Cretaceous syn-sedimentary tectonics related to the collision of Adria with the Eurasian plate (Vlahović et al. 2005; Korbar 2009). This is reflected in differentiated depositional settings within the ADCP domain during this time period (Vlahović et al. 2005; Ćosović et al. 2006; Korbar 2009; Brlek et al. 2012). The Cretaceous to Paleogene hiatus is interpreted as a consequence of diachronous and differential uplifts of various parts of the platform(s) in response to diachronous forebulging in front of the approaching Dinaridic orogen (Otoničar 2007; Korbar 2009).

\section{Conclusions}

(1) Several intraformational firmground and composite surfaces as well as Cretaceous to Paleogene regional subaerial unconformity, characterized by well-developed and diagnostic trace fossil and subaerial exposure features, were recorded in the Upper Cretaceous to Paleogene intra-platform peritidal carbonates of the southern part of the Adriatic-Dinaridic Carbonate Platform domain (central Dalmatia, Croatia).

(2) Thalassinoides boxworks (probably $T$. paradoxicus) of the Glossifungites ichnofacies characterize the submarine firmground stage in both types of intraformational discontinuities. Rhizogenic laminar calcretes developed subsequently inside burrows of the composite surface and indicate that this surface also experienced subaerial exposure.

(3) According to facies associations below and above the two recorded firmgrounds, these surfaces may have formed due to relative sea-level fall which caused a phase of omission. Different types of trace fossils recorded in the composite surface indicate that it may have experienced several stages of regression and transgression.

(4) The regional unconformity is characterized by biogenic (beta microfabric) calcretes with rhizoliths, including in situ Micocodium aggregates and root tubules with alveolar-septal structure, laminar calcretes, and pisoids (partly formed by bauxite calcretization), as well as typical paleokarst features (including in situ and re-sedimented speleothems).

(5) This unconformity was recorded across the ADCP domain and is interpreted as a consequence of diachronous and differential uplift of various parts of the platform in response to the formation of a forebulge in front of the approaching Dinaridic orogen.

(6) Ichnological and subaerial exposure features of the documented discontinuity surfaces, together with their stratigraphic implications, may be used in identification, characterization, and interpretation of discontinuities from carbonate successions of different stratigraphic age.

Acknowledgments This study was supported by the project "Stratigraphy and Geodynamic Context of Cretaceous Deposits in the NE Adriatic Region" (No. 181-1191152-2697) of the Ministry of Science, Education and Sports of the Republic of Croatia. We would like to thank Andrea Mindszenty and Francisco J. Rodríguez-Tovar for their very helpful comments and suggestions that greatly improved the manuscript. Facies Editor-in-Chief Franz Theodor Fürsich is thanked for his helpful comments and editorial work. We would also like to thank Marija Marguš, Elvira Bura Nakić, and Neven Cukrov from the Ruđer Bošković Institute Marine Station Martinska for accommodation during field studies, the Croatian Geological Survey Lab team for thin-section preparation, and Ladislav Fuček for field assistance.

\section{References}

Alonso-Zarza AM (1999) Initial stages of laminar calcrete formation by roots: examples from the Neogene of central Spain. Sediment Geol 126:177-191

Alonso-Zarza AM (2003) Palaeoenvironmental significance of palustrine carbonates and calcretes in the geological record. Earth Sci Rev 60:261-298

Alonso-Zarza AM, Jones B (2007) Root calcrete formation on quaternary karstic surfaces of Grand Cayman. Geol Acta 5: $77-88$

Alonso-Zarza AM, Wright VP (2010) Calcretes. In: Alonso-Zarza AM, Tanner LH (eds) Carbonates in continental settings: facies, environments and processes. Dev Sedimentol 61:225-269

Alonso-Zarza AM, Sanz ME, Calvo JP, Estévez P (1998) Calcified root cells in Miocene pedogenic carbonates of the Madrid Basin: evidence for the origin of Microcodium b. Sediment Geol 116:81-97 
Armenteros I (2010) Diagenesis of carbonates in continental settings. In: Alonso-Zarza AM, Tanner LH (eds) Carbonates in continental settings: geochemistry, diagenesis and applications. Dev Sedimentol 62:61-151

Bardossy G (1982) Karst bauxites, bauxite deposits on carbonate rocks. Dev Econ Geol 14:1-441

Bravi S, Carannante G, Masucci F, Pomoni-Papaioannou F, Simone L (2008) Dry and warm climatic conditions witnessed by sabkharelated evaporitic cycles in the "Middle Cretaceous" limestone of the Southern Apennines. GEOSED 2008, Bari, 21/09/08, Abstracts

Brlek M, Korbar T, Cvetko Tešović B, Glumac B, Fuček L (2012) Stratigraphic framework, discontinuity surfaces and regional significance of Campanian slope to ramp carbonates from central Dalmatia, Croatia. Facies. doi:10.1007/s10347-012-0342-0

Bromley RG (1967) Some observations on burrows of thalassinidean Crustacea in chalk hardgrounds. Q J Geol Soc Lond 123: $157-182$

Bromley RG (1975) Trace fossils at omission surfaces. In: Frey RW (ed) The study of trace fossils. Springer, Berlin-Heidelberg-New York, pp 399-428

Bromley RG (1996) Trace fossils-biology, taphonomy and applications, 2nd edn. Chapman and Hall, London 361

Buatois L, Mángano M (2011) Ichnology: organism-substrate interactions in space and time. Cambridge University Press, Cambridge 358

Cachão M, da Silva CM, Santos A, Domènech R, Martinell J, Mayoral E (2009) The bioeroded megasurface of Oura (Algarve, south Portugal): implications for the Neogene stratigraphy and tectonic evolution of southwest Iberia. Facies 55:213-225

Carannante G, Ruberti D, Sirna M (2000) Upper Cretaceous ramp limestones from the Sorrento Peninsula (southern Apennines, Italy): micro- and macrofossil associations and their significance in the depositional sequences. Sediment Geol 132:89-123

Christ N, Immenhauser A, Amour F, Mutti M, Tomas S, Agar SM, Alway R, Kabiri L (2012) Characterization and interpretation of discontinuity surfaces in a Jurassic ramp setting (High Atlas, Morocco). Sedimentology 59:249-290

Clari PA, Della Pierre F, Martire L (1995) Discontinuities in carbonate successions: identification, interpretation and classification of some Italian examples. Sediment Geol 100:97-121

Ćosović V, Drobne K, Moro A (2004) Paleoenvironmental model for Eocene foraminiferal limestones of the Adriatic carbonate platform (Istrian Peninsula). Facies 50:61-75

Ćosović V, Premec Fuček V, Gušić I, Jelaska V, Moro A (2006) The age of the Tilovica breccias in Central Dalmatia, Croatia. Micropaleontology 52:281-286

Ćosović V, Drobne K, Ogorelec B, Moro A, Koić M, Šoštarko I, Tarlao A, Tunis G (2008) Decastronema barattoloi (De Castro), characteristic fossil of the Palaeocene and the Eocene peritidal sediments from the Adriatic carbonate platform. Geol Croat 61:321-332

Cvetko Tešović B, Gušić I, Jelaska V, Bucković D (2001) Stratigraphy and microfacies of the Upper Cretaceous Pučišća Formation, Island of Brač, Croatia. Cret Res 22:591-613

D'Argenio B, Mindszenty A (1995) Bauxites and related paleokarst: tectonic and climatic event markers at regional unconformities. Eclog Geol Helv 88:453-499

Di Stefano P, Mindszenty A (2000) Fe-Mn-encrusted "Kamenitza" and associated features in the Jurassic of Monte Kumeta (Sicily): subaerial and/or submarine dissolution? Sediment Geol 132:37-68

Di Stefano P, Galácz A, Mallarino G, Mindszenty A, Vörös A (2002) Birth and early evolution of a Jurassic escarpment: Monte Kumeta Western Sicily. Facies 46:273-298
Dunham RJ (1962) Classification of carbonate rocks according to depositional texture. AAPG Mem 1:108-121

Durand N, Gunnell Y, Curmi P, Ahmad SM (2006) Pathways of calcrete development on weathered silicate rocks in Tamil Nadu, India: mineralogy, geochemistry and paleoenvironmental implications. Sediment Geol 192:1-18

Durand N, Monger HC, Canti MG (2010) Calcium carbonate features. In: Stoops G, Marcelino V, Mees F (eds) Interpretation of micromorphological features of soils and regoliths. Elsevier, Amsterdam, pp 149-194

Durn G, Ottner F, Tišljar J, Mindszenty A, Barudžija U (2003) Regional subaerial unconformities in shallow-marine carbonate sequences of Istria: sedimentology, mineralogy, geochemistry and micromorphology of associated bauxites, paleosols and pedo-sedimentary complexes. In: Vlahović I, Tišljar J (eds) Field trip guidebook, 22nd IAS meeting of sedimentology, Opatija, pp 209-251

Ehrenberg K (1944) Ergänzende Bemerkungen zu den seinerzeit aus dem Miozän von Burgschleinitz beschriebenen Gangkernen und Bauten dekapoder Krebse. Paläont Z 23:345-359

Ekdale AA (1992) Muckraking and mudslinging: the joys of depositfeeding. In: Maples CG, West RR (eds) Trace fossils. short courses in paleontology, Paleontological Society, 5:145-171

Ekdale AA, Bromley RG (1984) Sedimentology and ichnology of the Cretaceous-Tertiary boundary in Denmark: implications for the causes of the terminal Cretaceous extinction. J Sediment Petrol 54:681-703

Ekdale AA, Bromley RG, Pemberton GS (1984) Ichnology: the use of trace fossils in sedimentology and stratigraphy. SEPM Short Course, p 317

Embry AF, Klovan JE (1971) A late Devonian reef on northeastern Banks Island, NWT. Bull Can Petrol Geol 19:730-781

Esteban M, Klappa CF (1983) Subaerial exposure environments. In: Scholle PA, Bebout DG, Moore CH (eds) Carbonate depositional environments. AAPG Mem 33:1-96

Fleury JJ (1980) Les zones de Gavrovo-Tripolitza et du Pinde-Olonos (Grèce continentale et Peloponnèse du Nord). Èvolution d'une plateforme et d'un bassin dans leur cadre alpin. Publ Soc Géol Nord 4:1-651

Flügel E (2004) Microfacies of carbonate rocks. Analysis, interpretation and application. Springer, Berlin-Heidelberg-New York, p 976

Frey RW (1973) Concepts in the study of biogenic sedimentary structures. J Sediment Petrol 43:6-19

Fürsich FT (1979) Genesis, environments, and ecology of Jurassic hardgrounds. N Jb Geol Paläont Abh 158:1-63

GKRH (2009) Geološka karta Republike Hrvatske (Geological Map of the Republic of Croatia) scale 1:300.000. Hrvatski geološki institut (Croatian Geological Survey), Zagreb, 1 sheet

Gruszczynski M, Coleman ML, Marcinowski R, Walaszczyk I, Iasscs MCP (2002) Palaeoenvironmental conditions of hardground formation in the Late Turonian-Coniacian of Mangyshlak Mountains, western Kazakhstan. Acta Geol Polon 52:423-435

Gušić I, Jelaska V (1990) Upper Cretaceous stratigraphy of the Island of Brač within the geodynamic evolution of the Adriatic carbonate platform. Djela Jugosl Akad Znan Umjetn 69:1-160

Herwitz SR, Muhs DR, Prospero JM, Mahan S, Vaughn B (1996) Origin of Bermuda's clay-rich paleosols and their paleoclimatic significance. J Geophys Res 101:23389-23400

Hillgärtner H (1998) Discontinuity surfaces on a shallow-marine carbonate platform (Berriasian, Valanginian, France and Switzerland). J Sediment Res 68:1093-1108

Immenhauser A, Rameil N (2011) Interpretation of ancient epikarst features in carbonate successions - a note of caution. Sediment Geol 239:1-9 
Jackson ML (1956) Soil chemical analysis-advanced course. Published by the author, Madison, Wisconsin, p 894

Jaillard B, Guyon A, Maurin AF (1991) Structure and composition of calcified roots, and their identification in calcareous soils. Geoderma 50:197-210

James NP, Choquette PW (eds) (1988) Paleokarst. Springer, New York, p 416

Jenkyns HC (1991) Impact of Cretaceous sea-level rise and anoxic events on the Mesozoic carbonate platform of Yugoslavia. AAPG Bull 75:1007-1017

Jones B (1994) Diagenetic processes associated with plant roots and microorganisms in karst terrains of the Cayman Islands, British West Indies. In: Wolf GH, Chilingarin GV (eds) Diagenesis, IV. Dev Sedimentol 51:425-475

Jones B, Kahle CF (1985) Lichen and Algae-agents of biodiagenesis in karst breccia from Grand Cayman Island, British West Indies. Bull Can Petrol Geol 33:446-461

Kabanov P, Anadón P, Krumbein WE (2008) Microcodium: an extensive review and a proposed non-rhizogenic biologically induced origin for its formation. Sediment Geol 205:79-99

Kennedy WJ (1967) Burrows and surface traces from the Lower Chalk of southern England. Bull Brit Mus Nat Hist Geol 15:127-167

Kennedy WJ, Garrison RE (1975) Morphology and genesis of nodular chalks and hardgrounds in the Upper Cretaceous of southern England. Sedimentology 22:311-386

Klappa CF (1980) Rhizoliths in terrestrial carbonates: classification, recognition, genesis and significance. Sedimentology 27:613-629

Knaust (2008) Balanoglossites Mägdefrau, 1932 from the Middle Triassic of Germany: part of a complex trace fossil probably produced by burrowing and boring polychaetes. Paläont $\mathrm{Z}$ 82:347-372

Knaust D, Curran HA, Dronov AV (2012) Shallow-marine carbonates. In: Knaust D, Bromley RG (eds) Trace fossils as indicators of sedimentary environments. Dev Sedimentol 64:705-776

Korbar T (2009) Orogenic evolution of the external Dinarides in the NE Adriatic region; a model constrained by tectonostratigraphy of Upper Cretaceous to Paleogene carbonates. Earth Sci Rev 96:296-312

Korbar T, Cvetko Tešović B, Radovanović I, Krizmanić K, Steuber T, Skelton PW (2010a) Campanian Pseudosabinia from the Pučišća Formation on the Island of Hvar (Adriatic Sea, Croatia). Turkish J Earth Sci 19:721-731

Korbar T, Surić M, Fuček L, Mihelčić V, Veseli V, Drobne K (2010b). Geologija kornatskog otočja. In: Horvat M (ed) 4. hrvatski geološki kongres-vodič ekskurzija. Hrvatski geološki institut, Zagreb, pp 131-141

Košir A (2004) Microcodium revisited: root calcification products of terrestrial plants on carbonate-rich substrates. J Sediment Res 74:845-857

Kovačević Galović E, Ilijanić N, Peh Z, Miko S, Hasan O (2012) Geochemical discrimination of Early Palaeogene bauxites in Croatia. Geol Croat 65:53-65

Lj Babić, Zupanič J (2012) Laterally variable development of a basinwide transgressive unit of the North Dalmatian foreland basin (Eocene, Dinarides, Croatia). Geol Croat 65:1-27

MacEachern JA, Pemberton SG, Gingras MK, Bann KL (2007) The ichnofacies paradigm: a fifty-year retrospective. In: Miller WIII (ed) Trace fossils: concepts, problems, prospects. Elsevier, Amsterdam, pp 52-77

Mägdefrau K (1932) Über einige Bohrgänge aus dem Unteren Muschelkalk von Jena. Paläont Z 14:150-160

Marjanac T, Babac D, Benić J, Ćosović V, Drobne K, Marjanac Lj, Pavlovec R, Velimirović Z (1998) Eocene carbonate sediments and sea-level changes on the SE part of Adriatic Carbonate
Platform (Island of Hvar and Pelješac Peninsula, Croatia). In: Hottinger L, Drobne K (eds) Paleogene shallow benthos of the Tethys. Dela, Slov akad znan umetn (SAZU) 34:243-254

Martinuš M, Bucković D, Kukuč D (2012) Discontinuity surfaces recorded in shallow-marine platform carbonates: an example from the Early Jurassic of the Velebit Mt. (Croatia). Facies 58:649-669

Matičec D, Vlahović I, Velić I, Tišljar J (1996) Eocene limestones overlying lower Cretaceous deposits of Western Istria (Croatia): did some parts of present Istria form land during the Cretaceous? Geol Croat 49:117-127

Meléndez A, Alonso-Zarza AM, Sancho C (2011) Multi-storey calcrete profiles developed during the initial stages of the configuration of the Ebro Basin's exorrheic fluvial network. Geomorphology 134:232-248

Miller CR, James NP, Bone Y (2012) Prolonged carbonate diagenesis under an evolving late Cenozoic climate; Nullarbor Plain, southern Australia. Sediment Geol 261-262:33-49

Mindszenty A, D’Argenio B, Aiello G (1995) Lithospheric bulges recorded by regional unconformities. The case of MesozoicTertiary Apulia. Tectonophysics 252:137-161

Moro A, Skelton PW, Ćosović V (2002) Palaeonvironmental setting of rudists in the Upper Cretaceous (Turonian-Maastrichtian) Adriatic Carbonate Platform (Croatia), based on sequence stratigraphy. Cret Res 23:489-508

Myrow PM (1995) Thalassinoides and the enigma of Early Paleozoic open-framework burrow-systems. Palaios 10:58-74

Otoničar B (2007) Upper Cretaceous to Paleogene forbulge unconformity associated with foreland basin evolution (Kras, Matarsko podolje and Istria; SW Slovenia and NW Croatia). Acta Carsol 36:101-120

Pamić J, Gušić I, Jelaska V (1998) Geodynamic evolution of Central Dinarides. Tectonophysics 297:273-307

Pemberton SG, MacEachern JA, Saunders T (2004) Stratigraphic applications of substrate-specific ichnofacies: delineating discontinuities in the rock record. In: McIlroy D (ed) The application of ichnology to palaeoenvironmental and stratigraphic analysis. Geol Soc Lond Spec Publ 228:29-62

Radoičić R (1982) Carbonate platform of the Dinarides. Bull SANU 22:35-47

Radoičić R (1987) Bauxites of the internal Dinarides: stratigraphy and facies of bedrock and cover (Bosnia-Metohija sector). Rend Soc Geol It 9:277-280

Rameil N, Immenhauser A, Csoma AÉ, Warrlich G (2012) Surfaces with a long history: the Aptian top Shu'aiba Formation unconformity, Sultanate of Oman. Sedimentology 59:212-248

Rasmussen KA, Neumann AC (1988) Holocene overprints of Pleistocene paleokarst: Bight of Abaco, Bahamas. In: James NP, Choquette PW (eds) paleokarst. Springer-Verlag, BerlinHeidelberg-New York, pp 132-148

Rodríguez-Tovar FJ (2005) Fe-oxide spherules infilling Thalassinoides burrows at the Cretaceous-Paleogene $(\mathrm{K}-\mathrm{P})$ boundary: evidence of a near-contemporaneous macrobenthic colonization during the K-P event. Geology 33:585-588

Rodríguez-Tovar FJ, Martínez-Ruiz F, Bernasconi SM (2006) Use of high-resolution ichnological and stable isotope data for assessing completeness of a K-P boundary section, Agost, Spain. Palaeogeogr Palaeoclimatol Palaeoecol 237:137-146

Rodríguez-Tovar FJ, Pérez-Valera F, Pérez-López A (2007) Ichnological analysis in high-resolution sequence stratigraphy: the Glossifungites Ichnofacies in Triassic successions from the Betic Cordillera (southern Spain). Sediment Geol 198:293-307

Rodríguez-Tovar FJ, Puga-Bernabéu Á, Buatois LA (2008) Large burrow systems in marine Miocene deposits of the Betic Cordillera (Southeast Spain). Palaeogeogr Palaeoclimatol Palaeoecol 268:19-25 
Rossinsky V, Wanless HR, Swart PK (1993) Penetrative calcretes and their stratigraphic significance. Geology 20:331-334

Sakač K, Šinkovec B (1991) The bauxites of the Dinarides. Travaux ICSOBA 20-21:1-11

Sattler U, Immenhauser A, Hillgärtner H, Esteban M (2005) Characterization, lateral variability and lateral extent of discontinuity surfaces on a carbonate platform (Barremian to Lower Aptian, Oman). Sedimentology 52:339-361

Savrda CE (2012) Chalk and related deep-marine carbonates. In: Knaust D, Bromley RG (eds) Trace fossils as indicators of sedimentary environments. Dev Sedimentol 64:777-806

Savrda ChE, Browning JV, Krawinkel H, Hesselbo SP (2001) Firmground ichnofabrics in deep-water sequence stratigraphy, Tertiary clinoform-toe deposits, New Jersey slope. Palaios 16:294-305

Schwarz E, Buatois LA (2012) Substrate-controlled ichnofacies along a marine sequence boundary: the Intra-Valanginian discontinuity in central Neuquén Basin (Argentina). Sediment Geol 277-278:72-87

Schweitzer CE, Shirk AM, Ćosović V, Okan Y, Feldmann RM, Hoşgör I (2007) New species of Harpactocarcinus from the Tethyan Eocene and their paleoecological setting. J Paleont 81:1091-1100

Šinkovec B (1973) The origin of early Paleogene bauxites of Istria, Yugoslavia. 3ème Congr Intern d'ICSOBA Nice 1973:151-164

Steuber T, Korbar T, Jelaska V, Gušić I (2005) Strontium-isotope stratigraphy of Upper Cretaceous platform carbonates of the Island of Brač (Adriatic Sea, Croatia): implications for global correlation of platform evolution and biostratigraphy. Cret Res 26:741-756

Strasser A (1984) Black pebble occurrence and genesis in Holocene carbonate sediments (Florida Keys, Bahamas, and Tunisia). J Sediment Petrol 54:1097-1109
Tucker ME, Wright VP (1990) Carbonate sedimentology. Blackwell Science Publications, Oxford 482

Velić I (2007) Stratigraphy and palaeobiogeography of Mesozoic benthic foraminifera of the Karst Dinarides (SE Europe). Geol Croat 60:1-113

Vlahović I, Tišljar J, Velić I, Matičec D (2005) Evolution of the Adriatic Carbonate Platform: palaeogeography, main events and depositional dynamics. Palaeogeogr Palaeoclimatol Palaeoecol 220:333-360

Wilson MA, Curran HA, White B (1998) Paleontological evidence of a brief global sea-level event during the last interglacial. Lethaia 31:241-250

Wright VP (1994) Paleosols in shallow marine carbonate sequences. Earth Sci Rev 35:367-395

Wright VP (2007) Calcretes. In: Nash D, McLaren S (eds) Geochemical sediments and landscapes. Wiley, Oxford, pp 10-45

Wright VP, Tucker ME (1991) Calcretes: an introduction. In: Wright VP, Tucker ME (eds) Calcretes. IAS reprint series 2:1-22

Wright VP, Platt NH, Wimbledon W (1988) Biogenic laminar calcretes: evidence of calcified root mat horizons in palaeosols. Sedimentology 35:603-620

Wright VP, Platt NH, Marriot SB, Beck VH (1995) A classification of rhizogenic (root-formed) calcretes, with examples from the Upper Jurassic-Lower Carboniferous of Spain and Upper Cretaceous of southern France. Sediment Geol 100:143-158

Zamagni J, Mutti M, Košir A (2008) Evolution of shallow benthic communities during the late Paleocene-earliest Eocene transition in the northern Tethys (SW Slovenia). Facies 54:25-43

Zhou J, Chafetz HS (2009) Biogenic caliches in Texas: the role of organisms and effect of climate. Sediment Geol 222:207-225 